\title{
Arquiteturas da saúde na segunda metade do século XIX e os modelos de ensino nas academias portuguesas ${ }^{?}$
}

\section{Cybelle Salvador Miranda ${ }^{2}$ \\ Fernando Jorge Artur Grilo ${ }^{3}$}

RESUMO: O entrelaçamento histórico entre a construção de hospitais de raiz no Brasil e em Portugal na segunda metade do século XIX demanda a compreensão do contexto de formação e atuação acadêmica de seus projetistas, evidenciando a matriz fundamental da formação à altura: o desenho como técnica de concepção e representação da Arquitetura. Neste ensaio, adotaremos o olhar warburguiano ao entender a História da Arte como parte de uma teoria da cultura, em que fatores vários contribuem para a montagem de uma constelação iconográfica, a ser lida em sentido transdisciplinar que permita renovar e ampliar os cânones históricos preexistentes. Assim, a iconografia servirá de evidência para a compreensão do papel histórico, estético e social dos nosocômios, entendidos como monumentos urbanos em seus respectivos contextos. Temos como edifícios em foco neste estudo o Hospital D. Luiz I, da Real Sociedade Beneficente Portuguesa em Belém, projetado em 1870 pelo ex-aluno da Academia de Belas Artes de Lisboa, Frederico José Branco, e o Hospital de Alienados do Conde de Ferreira, pertencente à Santa Casa de Misericórdia do Porto, construído de raiz em 1868, sob a traça do engenheiro e lente proprietário da Cadeira de Arquitetura civil da Academia de Belas-Artes do Porto, Manuel de Almeida Ribeiro. Esses edifícios são ícones das inversões de capital de portugueses no Brasil e dos chamados brasileiros de "torna-viagem" em Portugal, representando as relações luso-brasileiras na segunda metade do século XIX.

PALAVRAS-CHAVE: Arquitetura Assistencial. Classicismo. Academias de Belas Artes. Relações Luso-brasileiras. Século XIX

ABSTRACT: The historical intertwining of production hospitals in Brazil and Portugal in the second half of the nineteenth century demands to understand the context of training and academic work of its designers, highlighting the fundamental matrix formation up to: the drawing as design technique and representation of architecture. In this essay, we will adopt the Warburg point of view to understand the History of Art as part of a Theory of Culture, where several factors contribute to the assembly of an iconographic constellation to be read in transdisciplinary sense to allow renovate and expand the existing historical canons. Thus, the iconography will serve as evidence
1. Destacamos o apoio da Coordenação de Aperfeiçoamento de Pessoal de Nível Superior (CAPES) por meio da Bolsa do Programa de Estágio Pós-doutoral no Exterior, Processo $\mathrm{n}^{\circ}$ BEX 6195/14-8, e ao Instituto de História da Arte (ARTIS), da Faculdade de Letras da Universidade de Lisboa pelo acolhimento durante o estágio.

2. Professora da Faculdade de Arquitetura e Urbanismo e do Programa de Pós-graduação em Arquitetura e Urbanismo na Universidade Federal do Pará; coordenadora do Laboratório de Memória e Patrimônio Cultural (LAMEMO), na mesma universidade. Email: <cybelle1974@hotmail.com>.

3. Docente do Mestrado em Arte, Património e Teoria do Restauro e do Doutoramento em História da Arte da Faculdade de Letras na Universidade de Lisboa. Email: <fgrilo@fl.ul.pt>. 
4. Ver Jacques Le Goff (2003).

5. Cf. Jacques Le Goff (2003, p. 538). for the understanding of the historical, aesthetic and social role of hospitals understood as urban monuments in their respective contexts. The objects in study are the Hospital Dom Luis I of the Royal Society Portuguese Beneficent in Belém, designed in 1870 by the former student of the Academy of Fine Arts of Lisbon Frederico José Branco and the Psychiatric Hospital of Conde de Ferreira. The last belongs to Holy House of Mercy of Porto, built for this purpose in 1868, under the traces of the engineer and Full Professor of Civil Architecture Chair of the Fine Arts Academy Port Manuel de Almeida Ribeiro. These buildings are icons of the Portuguese capital investments in Brazil and Brazilian called 'return-trip' in Portugal, representing the Portuguese-Brazilian relations in the second half of the nineteenth century.

KEYWORDS: Assistance Architecture. Classicism. Academies of Fine Arts. Luso- Brazilian Relations XIX Century.

Desvendando os caminhos da pesquisa

entendimento dos "documentos" da saúde como bens patrimoniais é algo recente e conflita com a urgência e as carências dos sistemas público e privado de assistência médica, sendo prementes e necessárias a identificação e a documentação desses bens e acervos. Segundo Le Goff, os monumentos são heranças do passado e os documentos, escolhas do historiador ${ }^{4}$. Para a escrita da história contemporânea, é preciso ter consciência de que um monumento é um símbolo de poder, devendo ser analisado no contexto, não só de sua produção, mas também da sua existência no presente; enquanto o documento "resulta do esforço das sociedades históricas para impor ao futuro - voluntária ou involuntariamente - determinada imagem de si próprias" ${ }^{5}$. A pesquisa em questão corrobora tal afirmação, uma vez que o estudo dos edifícios-sede dos hospitais D. Luiz I e Conde de Ferreira implicou a recolha de documentos escritos e iconográficos, os quais nem sempre são colocados à disposição do pesquisador, sendo este remetido a livros institucionais, de caráter celebrativo, publicados pelas sociedades gestoras dos respectivos hospitais. Recorre-se, em alternativa, à leitura da arquitetura como objeto no qual se materializam os desejos, ideologias e padrões do momento em que foi construído.

estudo da História da Arte, e da Arquitetura considerada como tal, compreende não apenas os vestígios materiais que sobreviveram à seleção dos tempos, mas também visa analisar, identificar e conservar as obras não executadas ou que se perderam, no todo ou em parte, ampliando a percepção entre o que foi planejado e as mudanças ocorridas na confecção da obra. Assim, Vítor Serrão se propõe a adotar a Cripto-História de Arte como um de seus ramos transversais, de modo que essa abordagem

contribui para dar vida a tais espécimes que diversas vicissitudes fizeram desaparecer do patrimônio presente. Ajuda a iluminar, a partir desse estudo, comportamentos específicos de estilos de artista, conflitos de gosto, preconceitos de mercados ou grupos sociais na circunstância influentes. Clarifica tendências, opções de encomenda e linhas de programação estética. Alarga 
a nossa percepção sobre o perfil biográfico de um mestre ou sobre as tendências que influenciam o percurso de uma oficina, esclarecendo as "zonas escuras" da sua actividadé.

Enquanto noção operativa, as bases da pesquisa cripto-artística assentam em quatro vertentes: a cryptanalysis, que trata a decifração de códigos de mensagens artísticas em obras das quais pouco se possui informações; a dedução, que seja o conhecimento produzido a partir da observação do ciclo artístico ou da produção geral do artista; a reconstituição, que parte de um fragmento para desvendar a estrutura completa; a incriação, ou estudo das obras que nunca chegaram a existir fisicamente no todo ou em partes. Esse método contribui para a abordagem em globalidade da arte, construindo a micro-história da produção cultural, na perspectiva ginzburguiana. $\bigcirc$ conceito de fragmento emerge como fundamental para essa vertente da disciplina, apropriada da Monadologia, de Leibniz, também adotada por Walter Benjamin e Friedrich Schlegel, entendido como individualidade orgânica, reflexo da totalidade. Cada obra é, portanto, um fragmento de um percurso autoral e histórico.

Sob essa perspectiva, cumpre-nos analisar os fragmentos que nos permitirão, através de um estudo estético em camadas de tempo passado, compreender os momentos de totalidade dos objetos a serem estudados, como partes do movimento de mudanças no panorama das cidades nas quais a arquitetura se inscreve. Contribuindo, portanto, para a consolidação do conhecimento necessário a garantir a preservação e a conservação material dos bens em questão, parte-se para o exercício de percepção dos objetos enquanto parte da cultura material, e sua interpretação.

Em "De Warburg a E. H. Gombrich Notas sobre um problema de método", Carlo Ginzburg se propõe a discorrer sobre um problema de método que foi central na pesquisa de Warburg: "a utilização dos testemunhos figurativos como fontes históricas" $"$. $\bigcirc$ conceito warburguiano de cultura compreenderia uma cultura em sentido quase antropológico, reunindo arte, literatura, filosofia, ciência, as superstições e as atividades manuais.

Segundo Ginzburg, Warburg pensava a História da Arte com um alcance mais amplo que desembocasse na teoria da cultura, negando leituras puramente "impressionistas" ou estetizantes das obras de arte. $\bigcirc$ pesquisador visava entender as obras à luz de testemunhos históricos, a fim de decifrar delas a gênese e o significado, e como as próprias obras eram fontes para a reconstrução histórica. Ginzburg salienta o cuidado que deve ter o investigador da arte ao atribuir conclusões a partir da fisionomia da obra, o que pode resultar em um reforço do que já se conhece por outros meios, que seriam mais graves quando, ao adotar a postura do historiador crítico de Marc Bloch, se tentasse desvendar a mentalidade de uma época a partir de testemunhos "involuntários". Daí redunda o problema da circularidade da interpretação.

Essa questão é deveras real quando se tende a pensar em termos de analogias, reproduzindo ideias e buscando o encaixe do objeto de estudo num
6. Cf. Vítor Serrão (2001, p. 11).

7. Cf. Carlo Ginzburg (1989, p. 42). 
8. Ver Clifford Geertz (1978, p. 13-41).

9. Conforme será explicado mais adiante, constatou-se que o suposto arquiteto cursou as Aulas da Academia de Lisboa, tendo abandonado o curso, sem concluí-lo.

10. Cf. Jussara da Silveira Derenji (1998, p. 92). contexto ou numa teoria pré-existente. A inclusão do método antropológico, seguindo a trilha de Geertz ${ }^{8}$, que entende a cultura como uma teia de significados, em que se deve escrutinar as singularidades ao invés das regularidades, nos permite ir além de uma ideia de que os indivíduos se regem pela mentalidade de época, mas que são capazes de infringi-la.

A relevância deste artigo deve-se à consolidação de estudos referentes ao patrimônio da saúde no Pará, especificamente na cidade de Belém, e as relações com a arquitetura hospitalar portuguesa construída "de raiz", a partir de finais do século XVIII, sob as influências do classicismo. Como edifícios a serem analisados, selecionamos o Hospital do Conde de Ferreira, o qual foi erigido sob encomenda de um brasileiro de torna-viagem, inspirado em um exemplar brasileiro, - Hospício Pedro II, do Rio de Janeiro, e o Hospital D. Luiz I, da Benemérita Sociedade Portuguesa Beneficente do Pará (também conhecido como Hospital da Beneficente Portuguesa), projetado por um suposto arquiteto português.

Para tal, buscaram-se referências relativas à formação dos arquitetos em Lisboa na segunda metade do século XIX, de modo a desvelar as influências trazidas a Belém, capital do Estado do Pará, nesse período, vide a presença de profissionais lusitanos atuantes na cidade e a significativa repercussão das linhas do classicismo que veio a ocorrer na cidade nos primórdios da Belle Époque na cidade.

Parte-se então da compreensão do papel desempenhado pela arquitetura clássica no Brasil e em Portugal na segunda metade do século XIX, retratando o fenômeno dos brasileiros de torna-viagem e evidenciando as peculiaridades do ensino da arquitetura nas Academias de Lisboa e do Porto, contribuindo para a celebração pelos 180 anos das academias de belas artes portuguesas. Tais distinções serão destacadas na configuração arquitetônica e estética dos dois objetos de estudo, que evidenciam similaridades na concepção do partido e da volumetria e efeitos estéticos próprios às concepções de ensino nas duas escolas.

A arquitetura clássica na segunda metade do século XIX no Brasil e em Portugal e os trânsitos culturais

estudo da produção de uma "nova" arquitetura na Belém da segunda metade do século XIX, tendo como paradigma o Hospital D. Luiz I da Beneficente Portuguesa, sendo precedido por duas obras emblemáticas - a primeira escola primária construída pelo governo (1874) e a sede do Banco Comercial do Pará, projetos do "arquiteto"9 português Frederico José Branco - ainda é uma lacuna na historiografia da arquitetura brasileira. Segundo Derenji, os prédios monumentais construídos em Belém entre 1870 e a República "manifestam um classicismo tardio"10, tendo como exemplos o Palacete Municipal (1868) e o Teatro da Paz (1869-1875). Segundo a autora, o emprego da simetria, das ordens sobrepostas, dos pórticos com arcadas ou colunas demonstra a intenção clássica dos projetistas, que também adotavam repertório palladiano, embora a leitura pudesse ser inexata, 
como na célebre discussão sobre a frontaria do Teatro da Paz ${ }^{11}$. Apenas nos anos de 1896-97, nota-se o acréscimo decorativo ao gosto do ecletismo sobreposto às fachadas sóbrias.

As incursões pombalinas na Amazônia trouxeram consigo os primeiros raios de um estilo clássico (por meio da obra de Antonio Landi no Pará), que teria seu esplendor no Brasil do $2^{\circ}$ Reinado, durante a segunda metade do século XIX. Após 1808, o estilo neoclássico torna-se oficial no Brasil, a fim de se satisfazer o gosto de uma corte acostumada a hábitos de morar e viver mais "civilizados". Assim, a convite de D. João VI, a missão composta por artistas franceses veio introduzir o academicismo francês na colônia. Grandjean de Montigny foi o paradigma dessa renovação, tornado autoridade pelo prestígio profissional como arquiteto premiado com o Prix-de-Rome, cuja formação acadêmica se destaca num país onde pontuavam os engenheiros militares. A criação da Academia Imperial de Belas-Artes foi decisiva para a difusão de uma nova arte: a arquitetura, em que a estética e a renovação dos materiais de construção tornaram-se determinantes. Nessa época, predominam edificações com matrizes europeias, rompendo com a tradição lusitana, em favor de uma linguagem internacional fixada pela École des Beaux-Arts de Paris, pela simetria e pelo rigor da composição das fachadas e plantas e fidelidade às ordens greco-romanas ${ }^{12}$.

Segundo Alberto Sousa ${ }^{13}$, na fase do $2^{\circ}$ Império (1840) surge uma produção inovadora e com características distintas dos outros períodos, de autoria de arquitetos formados pela academia, como Jacintho Rebello (Santa Casa, Palácio Universitário), Manoel Porto-Alegre (Cassino Fluminense), Teodoro de Oliveira (Casa da Moeda), bem como de arquitetos europeus, como Louis Hosxe (Beneficência Portuguesa), edificada na então capital do Império, Rio de Janeiro. $\bigcirc$ classicismo imperial se populariza, sendo difundido pelos mestres de obras que divulgam o repertório classicizante em casas que mantinham a tipologia interna colonial. $\bigcirc$ estilo assume ares de nacionalidade, incluindo características luso-brasileiras como azulejos, uso de pedra-de-galho (gneiss bege), arenito e lioz português. Nessa fase, o estilo expandiu-se pelo Brasil juntamente com a onda nacionalista da época.

classicismo imperial é definido pelo autor como uma arquitetura miscigenada, com a preservação de práticas e soluções da tradição lusobrasileira (reboco pintado no acabamento das fachadas em contraste com molduras em cantaria ou em massa pintada de corl e assimilação de influências não lusitanas - renascentistas e paladianas -, afastando-se dos modelos da antiguidade ${ }^{14}$.

Esse estilo desenvolveu-se com mais afinco na arquitetura civil, em edifícios cujas funções eram pouco usuais até o século XIX: escolas, hospitais, palácios, mercados, teatros, conforme corrobora Renato da Gama-Rosa Costa, ao afirmar que os primeiros hospitais brasileiros adotaram a estética "na forma ordenada e harmoniosa da arquitetura clássica" ${ }^{15}$. No Rio de Janeiro, se sobressai a atuação dos engenheiros, como Teodoro de Oliveira, projetista da Casa da Moeda (1834). Ainda nessa cidade, foram comuns o emprego do pórtico central
11. Ver Roseane Silveira de Souza (2010, p. 98), que relata ser a motivação para a reforma realizada no Teatro em 1904-1905 o aparecimento, em 1902, de uma rachadura no frontão. Essa falha ensejou o redesenho da fachada, incluindo o recuo do frontão e de uma colunata, a qual havia já sido motivo de críticas, uma vez que fora "projetada em número ímpar (sete), contrariando a paridade das regras clássicas da arquitetura, foi ajustada para ter seis colunas".

12. Ver Alberto Sousa (1994).

13. Ver Alberto Sousa (1994).

14. Ver Alberto Sousa (1994).

15. Cf. Renato da Gama-Rosa Costa (2008, p. 133). 
16. Ver Jussara da Silveira Derenji (1987).

17. Antonio José de Lemos, político maranhense, tornou-se o mais lembrado intendente da história de Belém devido às reformas urbanas que modificaram as feições da cidade, bem ao estilo francês, realizadas durante sua administração. Foi responsável pelo remodelamento de praças, parques, abertura de grandes avenidas e criação de código de posturas, bem como pela construção de prédios monumentais e fomento à arte erudita na sociedade local. Para mais informações, ver Maria de Nazaré Sarges (2002; 1998).

18. Ver Aldrin Moura de Figueiredo (2013).

19. Ver José Augusto França (1992).

20. Cf. José Augusto França (1992, p. 7). com frontão e colunas clássicas, o uso de sucessão de pilastras com abertura entre cada uma delas e as janelas em nicho, como no Hospício Pedro Il.

Contudo, a dificuldade de comunicação com a corte e a penúria da economia na primeira metade do século XIX mantiveram Belém à margem das motivações ideológicas do neoclassicismo imposto pela missão francesa. Apenas no momento em que a atividade extrativa da borracha adquire importância econômica, entre os 1870 e 1912, o ecletismo torna-se a expressão arquitetônica das mudanças de comportamento da população belenense. As firmas aviadoras atuam como intermediárias entre os interesses dos seringalistas e das empresas estrangeiras, sendo responsáveis pela introdução de materiais de construção modernos. Torna-se comum a importação de prédios inteiros, de pedra, como a Loja Paris N'América, ou em ferro - mercados, reservatórios, estações de trem, residências. No setor urbano, importa-se desde postes até relógios de origens francesa, inglesa, alemã e belga ${ }^{16}$.

A reformulação da cidade deu-se basicamente na administração do Intendente Antonio Lemos (1897-1912)17, que calçou e arborizou ruas, regulou as construções desde a disposição do lote até a fachada e retomou o tratamento urbanístico do bairro do Marco. O intendente promulgou, em 1901, o Código de Polícia Municipal, que regulava as edificações quanto a materiais, dimensões de cômodos e a adoção de porões e platibandas, o que ocasionou mudança significativa na fisionomia da cidade.

Belém não contava com mão de obra especializada, o que tornava os elementos decorativos por vezes excessivos, empregando as técnicas do passado. O Instituto Lauro Sodré (1871) era uma escola profissional gratuita para meninos órfãos, que formava serralheiros, marceneiros, gráficos e encadernadores. De lá saía o mobiliário usado nos prédios públicos. Segundo Figueiredo, havia preferência dos paraenses pela formação na Academia Portuense de Belas Artes, após a reforma de 1881, quando a escola passou a enfatizar, ademais da promoção das Artes e da Arqueologia, o ensino do desenho, da gravura e de outros cursos com aplicação às artes industriais, cujos conhecimentos adquiridos pelos discentes puderam ser aplicados no ensino profissional do Instituto Lauro Sodré, em Belém ${ }^{18}$.

Segundo José Augusto França ${ }^{19}$, o neoclassicismo surge em Portugal por volta do século XIX, por pareceres de arquitetos de origem e formação italianas, em oposição ao barroco tardio de origem alemã, considerado de mau gosto à época. $\bigcirc$ ato de maior significado cultural é a reavaliação, em 1801, dos planos do Palácio Real da Ajuda, de Manuel Caetano de Sousa, quando a obra, iniciada em 1795, é interrompida e reiniciada em 1802, nos ditames dos arquitetos de formação italiana, Fabri e Costa e Silva. A obra do palácio, dada como concluída em 1835, representa o modelo ideal da arquitetura neoclássica do Sul de Portugal. O autor descreve-o como: "[...] edifício imponente de 31.760 metros quadrados no seu plano inicial, baseado num duplo quadrado, com dois grandes pátios interiores, escadaria monumental na fachada principal, quatro torreões de ângulo, nenhuma igreja inserida no complexo civil"20. 
Já no Norte do país, o neoclassicismo está marcado pela elaboração da Academia da Marinha, projeto do arquiteto Carlos Amarante, aprovado por Costa e Silva, evidenciando uma ligação entre os arquitetos do Porto e de Lisboa, que "[...] articula uma experiência erudita, de origem italianizante a uma outra, empiricamente baseada numa corrente estilística inglesa"21. Essa corrente terá como suporte o capital proveniente no comércio do vinho do Porto, o que definirá a arquitetura chamada de Port Wine, que "a poderosa colónia britânica da cidade afeiçoara ao seu gosto neopaladiano, desde finais dos anos 60"22. As obras do Porto, ainda, apresentam certa alusão ao estilo barroco precedente, porém, a construção parcial do Hospital de Santo Antônio, encomendada ao inglês John Carr, na vigência da administração dos Almadas, marca a introdução de um estilo com marcante linguagem clássica.

Além das grandes obras arquitetônicas, as obras residenciais também sofreram influência do estilo neoclássico. Esse fato está marcado pela chegada em Portugal, na década de 90 do século XVIII, do arquiteto Francesco Saverio Fabri, que interveio na construção do Palácio do Marquês de Cartelo-Melhor, em Lisboa. $\bigcirc$ estilo neoclássico era adotado, principalmente, pelos "novos ricos", que optavam por residências elegantes e sóbrias, enquanto famílias mais antigas ainda tinham gosto pelo barroco assegurado por Manuel Caetano. No Porto, tem-se o Palácio dos Carrancas (1795), do arquiteto Costa Lima Sampaio, como exemplar que marcou a arquitetura residencial no contexto da tradição local. Mais para o norte, temos o Solar da Breijoeira, projeto iniciado em 1806, como exemplo, que, apesar de assumir uma estrutura neoclássica semelhante a do Palácio Real de Ajuda, entra em contradição ao utilizar elementos decorativos barrocos, caracterizando, portanto, uma obra híbrida.

José Augusto França observa que:

com a viragem do século observamos, assim, que a arquitectura portuguesa, oficial ou particular, se responsabiliza por uma viragem de gosto e estilo que se impôs tardiamente no País mal informado, ou só ocasionalmente, sem academias de ensino normalizado e que apenas no empirismo de soluções pombalinas pudera adquirir uma experiência conflituosa em relação à tradição barroca italiana que vigorara na sociedade joanina, por imposição áulica ou mimetismo provincial23.

autor destaca o papel de Costa e Silva para o neoclassicismo português, pois com seu regresso de uma aprendizagem italiana, foi o projetista de obras de relevo, sendo a mais importante o Palácio Real da Ajuda. Todavia, com sua mudança ao Brasil, acompanhando a corte, colocou-se um final nas realizações da arquitetura portuguesa, que sofreu total suspensão nos 30 anos conturbados que se seguiram ${ }^{24}$. França ainda aponta sucintamente as dificuldades enfrentadas pelas duas academias fundadas em 1836 em Portugal, com orçamentos diminuídos, más instalações e parcos instrumentos, de modo que o ensino que professavam fora acusado no parlamento, em 1850, de ser incompleto, errado, rotineiro, e as escolas tachadas de inúteis.
21. Cf. José Augusto França (1992, p. 8).

22. Cf. José Augusto França (1992, p. 8).

23. Cf. José Augusto França (1992, p. 10).

24. Ver José Augusto França (1992). 
25. Cf. José Augusto França (1992, p. 58).

26. Cf. Paulo Varela Gomes (2009, p. 11).

27. Ver Paulo Varela Gomes (2009).

28. Ver José Augusto França (1992).

29. Ver Raquel Henriques da Silva (1997).

30. Cf. Paulo Varela Gomes (2009, p. 18).
Em 1834, foram feitos os primeiros projetos para o Teatro Nacional de Declamação, sendo posteriormente contratado o arquiteto italiano Frederico Lodi para traçá-lo. O Teatro D. Maria II, inaugurado em 1846, é definido por França como "um edifício brilhante, dentro dos esquemas neoclássicos internacionais" 25 . Para o autor, esse é o marco inicial do discurso arquitetônico do romantismo, fase concluída 20 anos depois, com a remodelação dos Paços do Concelho.

Ressalte-se que, à época, poucas obras foram feitas de raiz, sendo, muitas, fruto de adaptações de casas religiosas, como foi o caso da Escola Politécnica de Lisboa ou do Palácio da Bolsa do Porto, o que ocasionava limitações às configurações dos partidos arquitetônicos.

Um estudo mais recente, de Paulo Varela Gomes, determinou como marco inicial do neoclassicismo português a morte de D. José l, em 1777, e como conclusão do ciclo o período entre 1846-50, após 40 anos de guerra estrangeira e civil. Como objetos de estudo, o autor elegeu o Palácio Real da Ajuda e o Edifício do Real Erário, ambos em Lisboa, o Hospital de Santo Antônio, no Porto e - Claustro do Mosteiro de Pombeiro de Ribavizela, no Minho. Todos os exemplos caracterizam-se como obras interrompidas. $\bigcirc$ primeiro projeto foi elaborado em 1796 e reformulado em 1802, tendo a um lado uma imponente igreja patriarcal e de outro uma espécie de museu ilustrado. Inicialmente planejado pelo arquiteto Manuel Caetano de Sousa, a forma efetivamente posta em execução foi elaborada por José da Costa e Silva, português formado na Academia de Bolonha, e Francisco Xavier Fabri, bolonhês de nascimento. A obra interrompeu-se em 1808 e foi retomada em 1813, "sob instruções vindas do Brasil, provavelmente de Costa e Silva que para lá partira em 1812, e continuou até 1818, sob a direcção directa de Fabri" ${ }^{26}$. O Erário novo foi também projeto de José da Costa e Silva, em 1789, no local onde hoje se situa o Jardim do Príncipe Real. Possuía base quadrada com 90 metros de lado e ao centro uma cúpula ${ }^{27}$.

Sobre o estudo do neoclássico luso, pouco tem sido feito, segundo Gomes, destacando como pioneira a obra de José-Augusto França, "A Arte Portuguesa de Oitocentos"28, e como o tema vem sendo abordado em publicações sobre a arte em Portugal em vários períodos. Contudo, houve pouca reflexão, excetuando-se estudos parciais como a tese Lisboa Romântica, de Raquel Henriques da Silva ${ }^{29}$ :

Todavia, não houve desde 1966, continua a não haver, praticamente nenhuma monografia dos grandes e médios protagonistas artísticos e arquitectónicos do período, com excepção do pintor Vieira Portuense, sobre o qual foi publicado o catálogo monográfico que referi, e do arquitecto Carlos Amarante (Eduardo A. Duarte, 2000)30.

Em finais do século XVIII, o Porto foi a cidade mais moderna, mais burguesa e mais civil, e lá se construiu o primeiro edifício neoclássico português, encomendado pela Misericórdia do Porto, em 1766. A influência inglesa local suscitou a contratação do arquiteto britânico John Carr, com experiência em projetos semelhantes. A concepção do edifício concentra-se numa planta simétrica voltada 
a um pátio quadrado, tendo ao centro uma capela hospitalar de planta centralizada. $\bigcirc$ piso térreo comportava os alojamentos dos escravos, capelães, estudantes de medicina, enfermarias dos loucos e serviços. $\bigcirc$ aspecto mais moderno do partido arquitetônico deve-se à concentração das instalações sanitárias e das canalizações de ar em corredor interno, liberando as faces exteriores para as enfermarias.

projeto foi executado à distância, com envio de desenhos em escala real para a moldagem dos pormenores construtivos mais difíceis, como a silharia de junta fendida (rusticatto), os balaústres, bases e capitéis das colunas, o que indica a novidade da ornamentação no contexto local.

Construído entre 1770 e 1824, o Hospital de Santo António deveria substituir o antigo Hospital da Santa Casa da Misericórdia do Porto sito à Rua das Flores. A primeira pedra da construção foi lançada a 15 de junho de 1771, porém apenas em 1824 se concluem as obras. $\bigcirc$ projeto de Carr - um edifício de quatro alas monumentais com paredes de tijolo, uma capela de cruz grega com zimbório localizada do pátio -, sofreu fortes alterações, em consequência da falta de meios disponíveis provocada em grande medida pelo aumento significativo do custo previsto, já que o edifício não foi construído em tijolo, mas sim em granito, o que veio, ainda, prejudicar o bom andamento dos trabalhos ${ }^{31}$.

Dessa forma, não se construiu a fachada traseira e os corpos norte e sul foram muito encurtados, pelo que o hospital apresenta planta em " $U$ ", com alçados de dois e três pisos, decorados por frontões, balaustradas, colunatas e urnas a rematar as cornijas. A fachada nascente ficou então sendo a principal e, apesar de não ter sido dotada da estatuária prevista, sua monumentalidade contrasta fortemente com a relativa simplicidade dos alçados laterais, desenvolvendo-se em cinco corpos de diferentes planos, entre os quais se destaca o central, com galeria aberta e seis colunas dóricas que suportam entablamento e tímpano. Segundo Rosário Carvalho, apesar das vicissitudes, o Hospital de Santo Antonio foi pioneiro na introdução da arquitetura anglo-palladiana no Porto entre os séculos XVIII e XIX, conferindo à cidade uma estética erudita ${ }^{32}$.

Os trânsitos culturais entre a ex-colônia e a metrópole no século XIX precisam da compreensão dos resultados dos fluxos migratórios ocorridos então, nos quais destacam-se a firmação das colônias portuguesas no Brasil Imperial e o progresso urbano levado ao Norte português pelos nativos retornados do Brasil. $\bigcirc$ Norte de Portugal é o lugar das principais evidências da saída e do retorno do "Brasileiro" 33 , sendo a cidade do Porto o local privilegiado do retorno. $\bigcirc$ migrante em retorno serve de exemplo de progresso e faz crescer a produção agrícola, além de emprestar capital a juros. As vilas recebem as novas elites liberais, que assumem o comando de confrarias e irmandades. Na segunda metade do XIX, as vilas ganham importância como sedes de administração no novo padrão liberal da República.

$\bigcirc$ retorno dos portugueses que obtiveram sucesso nos negócios em terras brasileiras gera a produção de uma arquitetura de linhas clássicas, com influência francesa, a qual esses "brasileiros de torna-viagem" buscam reproduzir em suas cidades-natal. Os capitais dos brasileiros de torna-viagem, que se assumem como
31. Ver Joaquim Jaime Ferreira-Alves (2005).

32. Hospital de Santo António (s.d.).

33. Cf. Miguel Monteiro (2000, p. 104). 
34. Cf. Miguel Monteiro (2000, p. 105).

35. Cf. Jorge Braga apud Monteiro (2000).

36. Cf. Monteiro (2000, p. 110)

37. Ver Isabel dos Guimarães Sá (2000).

38. Cf. Isabel dos Guimarães Sá (2000, p. 129). comendadores, servem para implantar as novas indústrias; suas marcas como beneméritos aparecem nas fachadas de hospitais, asilos, escolas e teatros "como actos com sentidos de distinção individual e vínculos às origens" ${ }^{\prime \prime}$.

Para Jorge Braga ${ }^{35}$, as soluções arquitetônicas empregadas por esses proprietários são reproduções desfocadas de soluções formais afrancesadas e do revitalismo de cariz italiano. Contudo, o autor destaca que a definição do partido geral e dos ambientes das novas moradias obedecia ao que rege a legislação da época, $2^{a}$ metade do século XIX, tanto em Portugal quanto no Brasil, não sendo arbítrio exclusivo dos proprietários, muito embora incorporadas por eles como sinais de refinamento e distinção social. As edificações burguesas apresentavam características como:

No que se refere à representação das fachadas, estas casas apresentam-se rebocadas e caiadas, ou cobertas com azulejos, estando presentes as cores do Brasil, com beirais de faiança, varandas estreitas com guardas de ferro forjado ou fundido, platibandas decoradas, lanternins, clarabóias e estatuetas, átrios decorados com azulejo, escadarias de madeiras preciosas, tectos de estuque, portas e janelas altas encimadas por bandeiras com vitrais coloridos, lustres de cristal e delicados móveis e porcelanas ${ }^{36}$.

Somente na segunda metade do século XIX, os emigrantes portugueses no Brasil adquiriram prestígio como doadores de recursos às misericórdias metropolitanas. Os beneméritos do século XIX acrescentaram às suas doações verbas destinadas à construção de estabelecimentos de assistência que tomariam o nome do doador, instituição de missas por alma do testador a serem assistidas por todos os internos na instituição, visitas oficiais quando do regresso dos doadores a sua terra natal. Como exemplo, temos o Hospital de Alienados Conde Ferreira e o Estabelecimento Humanitário Barão de Nova Sintra.

José Joaquim Leite Guimarães recebeu o título de Barão de Nova Sintra graças à instituição que criou. Trata-se de uma workhouse de estilo inglês, com uma fiação de seda nos terrenos adjacentes, na qual os internados trabalhavam. Quanto ao Conde de Ferreira, já era nobre quando legou recursos a Misericórdia do Porto. Joaquim Ferreira dos Santos, o maior benemérito da Misericórdia do Porto no século XIX, representa uma história de vida singular. Nascido em 1782, numa família de lavradores de Campanhã, emigrou para o Brasil como filho excluído da herança agrícola da família, em 1800. Entre seus negócios, destaca-se o tráfico negreiro entre Angola e Brasil. Seus problemas com a Lei brasileira de 1830, que extinguiu o tráfico negreiro (sendo posteriormente revogada), fizeram-no regressar ao Porto em 1832. Lá, reintegrado ao círculo de comerciantes, recebeu os títulos de Barão, Visconde e Conde entre 1842 e $1850^{37}$.

Com seu falecimento, em 1866, deixou em testamento recursos para a construção de 120 escolas e o hospital, o que representou "uma gigantesca lavagem da memória" desse personagem ${ }^{38}$. Segundo o notário, a inspiração para a construção do hospício fora uma conversa que tivera aquele com o imperador Pedro V, durante jantar no paço portuense. O hospital seria dependente da Santa 
Casa de Misericórdia do Porto, com caráter autônomo e privado, uma vez que a Misericórdia se eximia de qualquer responsabilidade financeira perante 0 estabelecimento. Inaugurado 15 anos depois do início das obras (1868), recebeu os primeiros internos a partir de exame feito pelos Doutores Senna e Júlio de Mattos.

Desde o final do século XIX, procurou-se restringir a emigração portuguesa para o Brasil por meio de medidas, seja com a lei de 1877 que estimulava o retorno a Portugal ou tentando deslocar o fluxo migratório para a África. Além disso, foram feitas campanhas como meio de fixar o indivíduo à pátria a fim de que, mesmo longe, mantivessem relação com ela ${ }^{39}$.

Apesar das restrições, o fluxo migratório para o Brasil se manteve elevado até 1930. Segundo especialistas, não houve um controle efetivo, já que existia interesse de ambos os países envolvidos na questão. Eram principalmente as parcelas empobrecidas do campo que viam na emigração a saída para os problemas, pois havia relatos fantasiosos de pessoas que enriqueciam no Brasil. Além disso, o governo português tinha na emigração uma válvula de escape para os conflitos de terra e as autoridades brasileiras se interessavam em manter tal fluxo para garantir mão de obra barata.

Um aspecto importante a destacar é que a imigração portuguesa no Brasil assumiu caráter predominantemente urbano ao longo do século XX, pois apesar de serem majoritariamente provenientes da zona rural, os imigrantes sentiamse atraídos pela cidade grande, onde as oportunidades e os salários eram maiores.

No início do século XX, com o projeto de modernizar a capital federal, - Rio de Janeiro se tornou um "canteiro de obras", ampliando o mercado de trabalho na construção civil e nos setores de serviços. Esse cenário tornou-se favorável à absorção da mão de obra estrangeira ${ }^{40}$.

A construção civil criou oportunidades para trabalhadores especializados como carpinteiros, ferreiros, soldadores, enquanto que os não qualificados se empregavam em transportes, comércio, como vendedores ambulantes. Às vésperas da Primeira Guerra Mundial, o número de portugueses que entraram no Brasil passara de 14.000 para 76.000 entre 1904 e 1913.

Porém, a aceitação dos migrantes nem sempre foi pacífica. A inserção dos portugueses na capital federal sofreu vários enfrentamentos por parte da população nacional. $\bigcirc$ chamado antilusitanismo influiu nas reações dos brasileiros aos imigrantes e a disputa pelo emprego se evidenciava nos conflitos. Dava-se preferência à mão de obra portuguesa, pois eram disciplinados e adaptavam-se a qualquer tipo de trabalho.

No entanto, além da discriminação, os portugueses estavam submetidos às mesmas situações de dificuldades e problemas que atingiam as demais camadas desfavorecidas. Os maiores problemas eram com a saúde, uma vez que muitas epidemias, dentre elas as de febre amarela, varíola, cólera e gripe assolavam a capital federal e se propagavam com facilidade, devido às más condições de trabalho e moradia. Muitos imigrantes vinham sozinhos e em meio à orfandade cultural e a solidão buscavam uma espécie de família em formas de solidariedade
39. Ver Ismênia de Lima Martins (2010).

40. Ver Ismênia de Lima Martins (2010). 
41. Ver Eulália Lobo apud Ismênia de Lima Martins (2010).

42. Ver Oliveira Martins apud Ismênia de Lima Martins (2010).

43. Ver Maria Helena Lisboa (2007).

44. Ver Alberto Claudio Rodrigues Faria (2008). mutualista e de organização, que caracterizavam a colônia portuguesa no Brasil, particularmente no Rio de Janeiro.

Ao final do século XIX, surgiram as sociedades de socorro mútuo, em que cada um deveria contribuir mensalmente com uma cota do salário, não dependendo apenas de caridade. Segundo Eulália Lobo ${ }^{41}$, o associativismo português, ao contrário das demais nacionalidades, não excluía os sócios brasileiros e estendia seus benefícios a indivíduos de outras nacionalidades.

Os imigrantes lusos que aportaram no Brasil, vieram em maior número a partir do século XIX e, segundo Oliveira Martins ${ }^{42}$, entre 1865 e 1873 totalizaram 71.499 , buscando enriquecimento e melhores condições de vida, haja vista que a monarquia de Portugal estava em uma crise econômica e a emigração portuguesa passou a ser elemento necessário à solução para os sem trabalho no campo e na cidade, além de contribuir para o equilíbrio da balança comercial lusa.

Os portugueses trouxeram consigo, além da disposição de superar os desafios, a vontade de ajudar seus compatriotas que necessitassem de ajuda humanitária. Formaram associações que amparavam seus patrícios nos momentos de dificuldade e assim criavam-se as Sociedades Beneficentes Portuguesas e as Casas de Misericórdia - a primeira sendo custeada por doações e pagamento de associados portugueses. Os Hospitais da Beneficente Portuguesa declararam sua sujeição à cultura compartilhada, reforçando o vínculo entre assistência, caridade e poder, constituindo um panorama social e arquitetônico significativo no norte do Brasil.

Sobre as academias de belas artes portuguesas e a aula de arquitetura civil

Os protagonistas deste estudo, Frederico José Branco e Manuel de Almeida Ribeiro, estavam ligados ao ensino acadêmico, o primeiro como discente da academia lisbonense, e o segundo, como lente da Academia Portuense. Cumpre conhecer os métodos e referências adotados no ensino da Arquitetura de então, a fim de melhor analisar os projetos dos hospitais por eles elaborados.

Segundo Lisboa ${ }^{43}$, a formação básica fornecida pelas academias portuguesas era constituída pelo Curso ou Aula de Desenho Histórico e pelos primeiros níveis da Aula de Desenho de Arquitetura civil. Aos docentes cabia orientar quanto às formas anatômicas, as dimensões e as proporções consideradas corretas, utilizando como técnica a cópia de estampas ou de modelos em relevo. Os docentes consideravam fundamental que os alunos conhecessem as figuras geométricas, tivessem noções de perspectiva, depois do que teriam noção das regras de invenção e da composição. $\bigcirc$ ensino privilegiava inicialmente o desenho à mão livre, com emprego acentuado da técnica do claro-escuro na representação das ordens clássicas, destacando-se, entre 1836 e 1880, o estudo dos Tratados de Vitrúvio, Palladio, Serlio e Vinhola na Academia de Lisboa ${ }^{44}$.

Quanto à Academia Portuense, o curso começava com o estudo das cinco ordens gregas e romanas, vantagens e emprego nos diferentes gêneros de 
edifícios; e noções elementares da arte da construção: distribuição das partes do edifício, decoração conveniente a cada função, solidez e segurança. Os métodos de ensino baseavam-se na cópia de modelos por estampa, e depois no desenhoprojeto de várias tipologias. No primeiro ano, deveriam estudar as decorações segundo Vinhola e Blondel e executar operações topográficas e de nivelamento. Como complemento teriam noções de aritmética, geometria, perspectiva, mecânica e história da arte. No segundo ano, estudariam a distribuição, apoiados em conhecimentos de hidráulica e mecânica, enquanto o terceiro ano seria dedicado ao estudo da construção.

Em comparação ao de Lisboa, o ensino no Porto "revela-se mais orientado para a formação de arquitectos, enquanto profissionais que deverão atender à execução prática dos seus projectos, e, não apenas, dominar as teorias necessárias à concepção e execução gráfica dos mesmos" 45 .

A dissertação de Rodrigues Faria procura analisar e compreender a Coleção de Desenho Antigo datada entre 1830 e 1935 e constituída com 1284 desenhos feitos nas Aulas Públicas de Desenho de Figura, Arquitetura Civil e de Gravura, entre 1830 e 1836, e a partir de 1836 na antiga Academia e Escola de Belas-Artes de Lisboa. Ainda como parte do acervo encontram-se trabalhos feitos nas aulas de ateliers de Paris e Roma, provas de concursos e exames realizados para as aulas de desenho, assim como provas para admissão e trabalhos de professores da Academia e Escola de Belas Artes de Lisboa, desenhos de pensionistas e projetos mostrados em concursos públicos. Como acréscimos a esses desenhos foram encontradas na faculdade obras de gravura (litografia, talho-doce e heliogravura) e fotografias do século XIX46.

Esses documentos são considerados um grande patrimônio pedagógico da Academia de Belas-Artes de Lisboa, pois retratam a formação de arquitetos, pintores e escultores, dos quais muitos também fizeram parte do corpo docente da academia, tornando importante o estudo desse acervo para a História da Arte portuguesa. Faria destaca que esse território se encontra ainda pouco explorado, sendo sentida a ausência de um estudo teórico da coleção, bem como de um inventário completo e sistematizado, tarefa que o autor se propõe a executar.

objetivo do estudo de Faria é compreender como foi formada essa coleção de desenhos e em que moldes essas obras foram incorporadas na instituição, bem como os contextos em que foram realizados os desenhos e quem são os seus autores. Por outro lado, interessa ao autor expor os modelos seguidos no ensino do desenho nas duas instituições majoritariamente representadas na coleção - Aula Pública de Desenho e antiga Academia e Escola de Belas-Artes de Lisboa.

Os desenhos foram segmentados por tipologias: desenho de cópia a partir de estampa, desenho de ornato, estátua, anatomia e desenho de modelo vivo - nu, panejamentos e cabeça -, e aspectos autorais, atendendo especialmente à presença de grandes mestres da arte portuguesa e artistas do sexo feminino.

Após a divisão entre Academia e Escola de Belas-Artes e a criação da Faculdade de Arquitetura, houve uma dispersão dos desenhos e gravuras entre o Museu
45. Cf. Maria Helena Lisboa (2007. p. 117)

46. Ver Alberto Claudio Rodrigues Faria (2008). 
47. Ver Alberto Claudio Rodrigues Faria (2008).

48. Ver Alberto Claudio Rodrigues Faria (2008).
Nacional de Belas-Artes, que mais tarde se dividiu em Museu Nacional de Arte Antiga e Museu Nacional de Arte Contemporânea (atual Museu do Chiado), a Academia Nacional de Belas-Artes e a Faculdade de Arquitetura de Lisboa. $\bigcirc$ inventário foi apresentado segundo as normas de inventariação museológica, sendo criada uma base de dados para pesquisa e consulta do inventário. Nota-se, contudo, que a base não se encontra acessível ao público, estando disponíveis apenas algumas fichas de inventário no site do Museu da Faculdade de Belas-Artes da UL (FBAUL). Rodrigues Faria refere ainda a criação de um Gabinete de Desenho da FBAUL, com o intuito de acondicionar as obras, por iniciativa da Professora Doutora Luísa Arruda ${ }^{47}$.

Os desenhos inventariados pertenciam às aulas de anatomia artística, desenho do modelo vivo/figura do natural, composição de ornato em aquarela, composição de ornato, desenho arquitetônico, desenho de arquitetura civil, desenho de figura do antigo, desenho de figura por estampa, desenho de ornato e do relevo por estampa, desenho histórico - classe de estudo gesso (1. . classe).

A Coleção de Desenho Antigo da FBAUL divide-se em dois grandes grupos regidos por um critério cronológico: antes da fundação da ABAL (18301836) e após a fundação (1836-1935). $\bigcirc$ primeiro grupo diz respeito a um conjunto de 761 desenhos, datados entre 1830 e 1836, procedentes da aula de desenho de Arquitetura civil, a Aula Pública de Desenho criada por alvará da Rainha D. Maria I, de 23 de agosto de 1781. A análise efetuada a esse conjunto de obras permitiu observar, segundo Faria ${ }^{48}$, que no ensino dessa aula foram eleitos os modelos das tratadísticas italiana e francesa dos séculos XVI, XVII e XVIII, com destaque para o compêndio do arquiteto italiano Giacomo Barozzi Vignola Regola delli cinque ordini d'architectura (1562). $\bigcirc$ segundo grupo engloba 523 desenhos referentes à produção acadêmica e artística dos discípulos, ex-discípulos e professores da Academia e Escola de Belas-Artes de Lisboa, no período que vai desde 1836 até 1935. Fazem parte desse conjunto, provas de concursos e exames da Aula de Desenho, provas de admissão ao professorado, desenhos para um compêndio de arquitetura, remessas de pensionistas e três projetos apresentados para o concurso público realizado em 1842, destinado à edificação de um monumento em homenagem ao Duque de Bragança.

Os desenhos procedentes dos concursos e exames da Aula de Desenho referem-se na sua maioria aos objetos premiados nessas competições, criadas com - objetivo de avaliar o aproveitamento e as capacidades dos discípulos, mas também incentivar o seu desempenho artístico. Também se encontra um conjunto de desenhos de alunos aprovados com distinção e reconhecidos como exemplos de mérito pelo sistema de ensino da Academia e Escola de Belas-Artes de Lisboa, sendo essas obras, por isso, uma fonte esclarecedora para entender o tipo de desenho que era valorizado na instituição. $\bigcirc$ autor conclui que

[a]s edições das obras de Vitrúvio, Palladio, Serlio e Vignola, que como se disse no capítulo 2.4 (Parte II), vieram da Aula Pública de Desenho para ABAL, constituíram o suporte teórico para o ensino da arquitectura na Academia no seu período inicial, sendo que a partir 1880 a 1920, são os tratados de Blondel (Cours d'arquitecture) ${ }^{423}$, Francesco Milizia (1725- 
1798) 124, Quartrèmere de Quincy (1755-1 849) e Jean-Nicolas-Louis Durand (1760-1 834)425, os referentes teóricos mais utilizados no ensino da arquitectura na EBAL 42649.

Dentre os trabalhos expostos e premiados nas mostras trienais, exposiç̃ẽes que exibiam os melhores trabalhos executados pelos discentes segundo as classes, alguns eram emoldurados e exibidos nas salas de aula, enquanto outros eram arquivados em pastas, que certamente eram guardadas nas salas de aulas, também para servir de modelo correto de representação de modelos. Tais exemplares eram de grande valia para o efeito didático do ensino.

Faria destaca ainda que a chegada à academia dos desenhos produzidos pelos pensionistas no estrangeiro, tornada obrigatória a partir de 1871, serviu decerto como veículo para a introdução na instituição dos modelos e valores dos academismos francês e romano do século XIX.

Todos os alunos da ABAL eram obrigados a fazer a Aula de Desenho de Arquitetura Civil, independente do curso que viessem a escolher. Com a criação do curso de desenho em 1837, as aulas de desenho de arquitetura são iniciadas apenas no segundo ano e complementam as aulas de desenho antigo, desenho anatômico e desenho de ornato. Já com as mudanças ocorridas em 1881, o ensino do desenho de arquitetura é passado para a primeira parte da terceira cadeira de desenho arquitetônico e arquitetura civil, nos segundo, terceiro e quarto anos do curso.

O ensino no Curso de Arquitetura era tanto baseado em tratadística de grandes mestres como também em manuais e desenhos de autoria dos próprios docentes. Em documento de 20 de março de 1861, encontra-se o programa de ensino baseado nos manuais e coleções de cada aula; especificadamente nas Aulas de Arquitetura Civil, as obras de Sequeira, Blondel e Durand eram importantes materiais de estudo.

Na coleção correspondente ao Curso de Arquitetura, Faria verificou que muitos alunos trabalharam com técnica aguada. Além disso, faziam uso das ordens e tinham conhecimento referente às terminologias de partes e seções de uma construção, sendo o estudo da arquitetura clássica parte do ensino da Academia e Escola de Belas-Artes de Lisboa entre 1836 e 1935.

Conclui-se que a base do aprendizado da Arquitetura dava-se em similaridade às demais artes plásticas, sendo a emulação a prática corrente para a produção dos projetos, em que a variação de partidos e formas era, portanto, limitada, restringindo-se à reprodução das gravuras dos tratadistas, sujeita à seleção de temas menos complexos, com simplificação dos ornatos e pouca movimentação das fachadas.

Hospital D. Luiz I da Real Sociedade Portuguesa Beneficente do Pará e o Arquiteto Frederico José Branco

O interesse em estudar a formação dos arquitetos na academia de Lisboa prende-se ao nome do "arquiteto" projetista do hospital da benemérita
49. Cf. Alberto Claudio Rodrigues Faria (2008, p. 8283 , grifo do autor). 
50. Cf. Livro de Matrículas (1842-1850, p. 100). Faculdade de Belas-Artes. Universidade de Lisboa.

51. Ver Revista Universal Lisbonense $2^{\text {a }}$ série Tomo $\mathrm{V}$, $\mathrm{n}^{\circ} 26$ de 5 de janeiro de 1853. Disponível em: http:// hemerotecadigital.cm-lisboa.pt/OBRAS/RUL/18521853/1852-1853.htm
Sociedade Portuguesa Beneficente do Pará. Frederico José Branco, nosso personagem exemplar, emerge no livro que narra a história da sociedade e do hospital, batizado com o nome do monarca português que teve como patrono, D. Luiz I. Nos livros de matrículas depositados nos arquivos da Faculdade de Belas Artes da Universidade de Lisboa foi identificado o registro do discente no ano letivo de 1851 a $1852^{50}$. No mesmo livro, à página 150 se descreve

Frederico José Branco com desenove annos de idade, filho de Henrique José Branco, natural de Lisboa; matriculado Discipulo Voluntario, na Aula de Desenho Historico em trinta um de outubro de mil oito centos cincoenta e um.

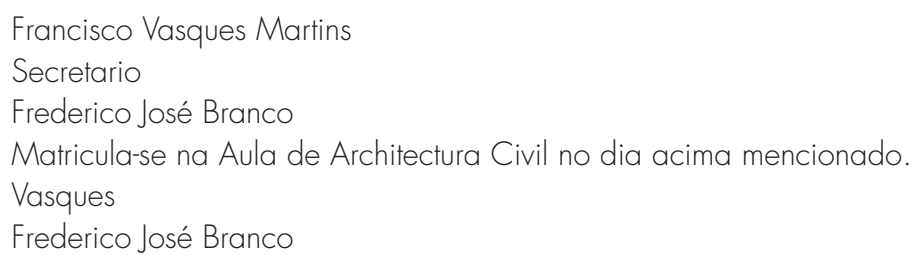

Na listagem de discípulos voluntários, aparece sob o número 60, com a data do despacho: "Fabris 24 no ano 185031 outubro 1851; Oficios ou profeçoes: Canteiro. Aulas que frequenta: Figura, Escultura, pintura. Turmas $2^{a \prime \prime}$. Em outra lista, aparece sob o número 60, "Data do despacho Fabril 24 de Novembro 185031 outubro 1851. Empregos que tem: Canteiro laparece riscado a lápis); Aulas que frequenta: Figura, Escultura". Na lista de frequência subsequente, sem indicação da aula, aparece no número 55, sem registro de faltas ou indicação do comportamento. "Aulas que frequentou: Figura; Turmas $1^{\text {a }}$; Considerados em Arguencias: 23; Observações: Suspenço em 21 de Dezembro 1854, por Ordem do $\| m^{\circ}$ Sr. Domingos Gonçalves por não .... cumprimentos o Professor Substituto desta aula". Daí depreende-se que deixou de frequentar as aulas e passou à atividade profissional com os parcos conhecimentos adquiridos na academia.

A Revista Universal Lisbonense ${ }^{51}$, em texto sobre Exposição de BellasArtes, narra que, no dia 30 de dezembro de 1852, a Academia de Bellas-Artes de Lisboa abriu sua exposição com a presença da rainha e do rei, referido como conhecedor das artes de desenho. Cita o articulista que quanto à história da academia, irá transcrever o relatório do secretário, e que há muito detratores da instituição, por isso, como resposta, transcreve alguns trechos do discurso recitado pelo Professor Francisco de Assis Rodrigues, escultor e erudito.

No discurso transcrito, o professor refere os nove anos da primeira exposição da academia, e afirma que se não se cumpriu a periodicidade expressa nos estatutos deveu-se às revoluções políticas, que obrigaram por duas vezes o fechamento das aulas, bem como à falta de recursos. Enaltece o apoio dado pelo governo para as artes, e relata que as aulas vinham sendo oferecidas regularmente, com exceção dos anos de 1846 a 1847 e 1847 a 1848, por ter estado tomada por militares a parte da escola dedicada à Arquitetura civil. No ano em questão, 1852, somado aos dois anos anteriores, foram ao todo 490 matriculados, sendo 
que compareceram às aulas noturnas 88 alunos fabris. Refere os discentes premiados e os valores a eles atribuídos.

Dá a saber que os agregados vinham tendo bastante trabalho, e no caso dos agregados à aula de arquitetura civil, foram solicitados pelo governo em comissões ou no desenho de projetos de arquitetura. Acrescenta, sempre se dirigindo à rainha, as edições dos elementos de desenho feitas pelo Professor de Desenho Histórico, Joaquim Rafael, os compêndios de geometria e perspectiva compilados pelo Professor Substituto de Arquitetura Civil José da Costa Sequeira e a compra de livros. Destaca "a primorosa obra de architectura civil do cavalheiro Luiz Canine, de cinco volumes de estampas, em folio, e dez volumes de texto"52 que o inspetor geral da academia mandara comprar. Aproveita para destacar à rainha o estado deplorável das estátuas e obras do antigo para uso dos respectivos estudos.

A seguir, transcreve um extrato do discurso do Sr. Assis que enaltece o desenho como a base para o conhecimento em várias áreas, "as artes plásticas são um bello e excellente dialecto, uma linguagem universal" 53 . E acrescenta que se as artes do desenho precisam de outras ciências, a recíproca é verdadeira, ou seja, ela não está em condição subordinada às ciências e outras artes. Relaciona a aplicação dos estudos de desenho ao desenvolvimento das manufaturas na Europa, de modo que a academia vinha desempenhando seus dois papeis: criar artistas doutos e difundir as regras do desenho às classes fabris e secundárias. Responde veementemente aos difamadores da academia, acentuando a confusão geral entre os artífices e os artistas, que se traduzia em obras malfeitas e rudes, o que, por sua vez, refletia o estado de uma sociedade e seu grau de civilização.

Na edição n 32, de 17 de fevereiro de 1853, a revista continua a transcrição do Catálogo da Exposição da Academia de Bellas Artes ${ }^{54}$ - iniciada na edição de 13 de janeiro, com as partes de desenho histórico e pintura histórica, e na edição de 10 de fevereiro de 1853 -, com as obras de escultura da Aula de Arquitetura Civil, destacando do Professor Proprietário João Pires da Fonte, o projeto de um palácio de cortes, do Professor Substituto José da Costa Sequeira, o projeto para o monumento sepulcral de sua majestade imperial D. Pedro duque de Bragança, e projeto do edifício que se construiu na Praça da Alcântara, destinado ao Quartel do batalhão naval, além de uma coleção de exemplares para a composição de um tratado fácil e metódico de teoria e prática das sombras para servir de compêndio aos alunos da respectiva aula; outra coleção destinada ao ensino da geometria prática, com princípios de desenho linear adequados a todas as artes, "pondo-se ao alcance das mais limitadas intelligencias"55; vários exemplares de algumas peças das cinco ordens de arquitetura de Vinhola, desenhados e aquarelados pelo referido professor, os quais serviam de originais aos seus discípulos; além de projeto para casa de abastado proprietário e um edifício de Paços de Concelho. Seguem-se obras de acadêmicos e artista agregado, bem como do Sr. José Callado; uma coleção de estudos da teoria e prática das sombras, copiadas dos originais confeccionados pelo professor substituto da mesma aula; uma coleção de estudos elementares das cinco ordens;
52. Cf. Revista Universal Lisbonense $2^{\mathrm{a}}$ série Tomo $\mathrm{V}$, $\mathrm{n}^{\circ} 26$ de 5 de janeiro de 1853 , p. 302.

53. Cf. Revista Universal Lisbonense $2^{\mathrm{a}}$ série Tomo $\mathrm{V}$, $\mathrm{n}^{\circ} 26$ de 5 de janeiro de 1853 , p. 303.

54. Cf. Revista Universal Lisbonense $2^{\mathrm{a}}$ série Tomo $\mathrm{V}$, $\mathrm{n}^{\circ} 32$ de 17 de fevereiro de 1853 , p. 376.

55. Cf. Revista Universal Lisbonense $2^{\mathrm{a}}$ série Tomo $\mathrm{V}$, $\mathrm{n}^{\circ} 32$ de 17 de fevereiro de 1853, p. 377. 
56. Cf. Revista Universal Lisbonense $2^{\mathrm{a}}$ série Tomo $\mathrm{V}$, $\mathrm{n}^{\circ} 32$ de 17 de fevereiro de 1853 , p. 378

57. Ver Regina Anacleto (2000).

58. Ver Jarbas Barbosa apud Jane Felipe Beltrão (2007, p. 146).

59. Cf. Magda Nazaré Pereira da Costa (2006, p. 9).

60. Cf. Magda Nazaré Pereira da Costa (2006).

61. Cf. Jane Felipe Beltrão (2007).

62. Cf. Jane Felipe Beltrão (2007, p. 148).
"Varios desenhos e estudos dos srs. Joaquim Antonio de Sousa, Frederico José Branco e de outros discípulos da mesma aula"56.

De nosso personagem, Frederico José Branco, encontram-se, ademais, registros de sua atuação em Belém, em notícias de jornal alusivas a desavenças com um dos sócios da Real Sociedade Beneficente Portuguesa do Pará, bem como sobre a sua participação na construção do Real Gabinete Português de Leitura do Rio de Janeiro ${ }^{57}$.

A construção de hospitais na Belém do século XIX justifica-se pela necessidade de atender aos acometidos pelas epidemias que assolaram a capital paraense. A mobilização da sociedade para enfrentar moléstias como febre amarela, varíola e cólera denotou a ineficiência do poder público, uma vez que "no passado, a ideia errada - incorporada no Brasil - de que todas as doenças transmissíveis seriam erradicadas, fez com que as equipes de vigilância baixassem a guarda"58. Assim sendo, a falta de estudos ligados à ciência médica corroborou para a disseminação das epidemias, o que vitimou milhares de pessoas.

A falta de conhecimento sobre a etiologia das moléstias trouxe à tona ainda um acirrado conflito ideológico entre os médicos, que divergiam quanto aos possíveis fatores que motivaram as epidemias e o tipo de terapêutica a ser aplicada aos doentes, ao mesmo tempo que o perigo da contaminação aguçou também a "compaixão" a "caridade" de todos que se viram direta e indiretamente ameaçados por aqueles males ${ }^{59}$.

Segundo Costa $^{60}$ e Beltrão ${ }^{61}$, o porto de Belém foi acesso de entrada para as doenças trazidas por navios que aportaram na cidade, onde higiene e saneamento básico eram inexistentes, facilitando a proliferação de doenças que vitimaram especialmente os mais pobres.

Em maio de 1855, durante a terceira pandemia, apareceu em Belém do Grão-Pará uma doença de caráter maligno, importada pela galera portuguesa Deffensor. A embarcação atracou no porto da cidade no dia 14 daquele mês trazendo colonos procedentes da cidade do Porto, região do Douro, em Portugal, cujas imediações eram assoladas pela doença. Era o início da saga brasileira. Do Pará a epidemia atingiu a Bahia em junho de 1855 e em jutho chegou ao Rio de Janeiro, capital do Império, para desespero da corte (Cooper, 1986). Houve ocorrências, também, em Pernambuco e no Ceará (1861-1862) ${ }^{62}$,

Em outubro de 1874, lançou-se a pedra fundamental do edifício hospitalar da Beneficente Portuguesa do Pará, cuja inauguração ocorreu no dia do aniversário de D. Luiz I, em 29 de abril de 1877. O Hospital Dom Luiz I da Beneficente Portuguesa foi idealizado pela colônia portuguesa no Pará. $\bigcirc$ primeiro nosocômio foi localizado num prédio sito à Praça da República, próximo ao Café Chic e vizinho ao antigo Hotel da Paz, inaugurado em 1867, sendo conhecido como Asilo Português da Infância Desvalida. Porém, mostrando-se o asilo insuficiente para atender à demanda, foi instalada, provisoriamente, uma enfermaria de dois pavimentos localizada na Rua Santo Antônio, conhecida como Casa de Saúde da 
Real Sociedade Portuguesa Beneficente. Até que, em maio de 1873, é levantada a proposta de compra de um dos dois lotes situados na Estrada Dois de Dezembro latual Avenida Generalíssimo Deodoro) ${ }^{63}$.

Acatada a aquisição do terreno pela diretoria da Sociedade Portuguesa Beneficente, contratou-se o arquiteto Frederico José Branco, idealizador do projeto que, segundo a diretoria, atendia às exigências de higiene e saúde da época: edifício amplo, com boa insolação e luminosidade, bastante ventilado e arejado:

artista compreendeu bem o que desejava e revelou de modo inconcusso a sua competência traçando um projeto geral de um grandioso edifício, devendo ser uma parte executada para servir às exigências de então e outra quando mais tarde o desenvolvimento interno do serviço hospitalar requeresse uma locação maior 64 .

Hospital Dom Luiz I é inaugurado com 253 leitos divididos em três setores: masculino, feminino e maternidade. Seus andares térreo e superior são destinados aos quartos individuais e serviços cirúrgicos; nos porões habitáveis encontram-se enfermarias, consultórios e serviços de apoio diagnóstico. $\bigcirc$ estabelecimento de saúde ocupa a totalidade do quarteirão em que se situa, com pavilhões no alinhamento lateral esquerdo e de fundo; e o bloco principal recuado frontalmente.

A preferência pelo terreno da Travessa Dois de Dezembro, sito em zona de terra firme e de cota elevada, ratificou a preocupação que emanou do meio político-científico em promover a higienização da cidade. $\bigcirc$ bairro de Nazaré, onde foi implantado o hospital, contava com largas artérias e terrenos amplos, uma vez que nessa zona da cidade localizavam-se casas de recreio denominadas rocinhas. Nesse ínterim, foram construídos cemitérios, haja vista a proibição de serem efetuados enterros dentro das igrejas, ações que visavam a contenção das epidemias.

Dessa forma as estratégias apontadas pelos médicos, imbuídos de uma concepção higienista, para garantir a salubridade dos espaços coletivos da cidade resultaram especificamente para os hospitais [...], (nos quais) cuidar de doentes deixava de ser apenas um exercício da caridade e da solidariedade cristã, para expressar também uma medida profilática de higiene cívica, cujo objetivo era manter a ordem social. Logo, no tempo das epidemias, essa secularização e consequente racionalização da sociedade Oitocentista, transformou o hospital em um espaço de experiência da ciência médica a serviço do poder público, sem contudo, acarretar a perda total de sua antiga função de amparo e de consolo diante do padecimento dos doentes ${ }^{65}$.

projeto elaborado por Frederico José Branco, ademais de representar um monumento de destaque para a colônia portuguesa do Pará, obedeceu aos preceitos higienistas - afastamento dos limites do lote; planta denteada, que possibilitava a ventilação e iluminação; construção elevada sobre porões, evitando o contato da umidade com os pisos.

$\bigcirc$ edifício adotava formato alongado com térreo em alvenaria de pedra, porão usado inicialmente "como depósito"66 (Figura 1). Acima do térreo, ergueu-se
63. Ver História da Benemérita Sociedade... (1974).

64. Cf. História da Benemérita Sociedade... (1974, p. 71).

65. Cf. Magda Nazaré Pereira da Costa (2006, p. 58-59).

66. Ver Cibelly Alessandra Rodrigues Figueiredo (2015). 
67. Ver Cybelle Salvador Miranda; Jane Felipe Beltrão; Marcio Couto Henrique (2013). o primeiro pavimento, com partido arquitetônico semelhante ao anterior e um segundo pavimento ocupando somente o corpo central. Em 1912, acresceu-se o segundo pavimento sobre o corpo central, alongando-se no sentido transversal do terreno, a fim de acomodar o atendimento às mulheres.

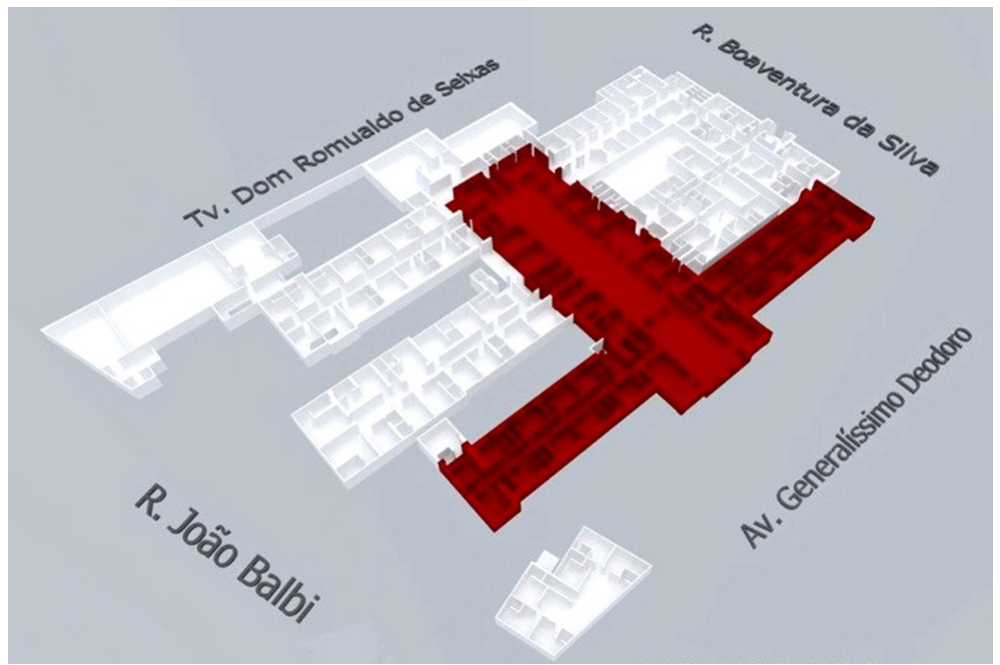

Figura 1 - Maquete definindo a forma do térreo e $1^{\circ}$ pavimento, após o acréscimo de 1912, editada pelos autores a partir de maquete feita por Cibelly Figueiredo em Hospital D. Luiz I da Benemérita Sociedade Portuguesa Beneficente do Pará como documento/ monumento, 2015.

Do panorama traçado, podemos vislumbrar os desdobramentos estéticos dos modelos de ensino lisbonense e portuense na concepção morfológica dos objetos arquitetônicos da saúde, destacando a volumetria e o caráter advindo do repertório decorativo empregado nas fachadas nos respectivos hospitais.

$\bigcirc$ Hospital Dom Luiz I da Beneficente Portuguesa (Figura 2) é um edifício de dois pavimentos, mais porão - delimitados por meio de cornijas nervuradas contínuas. Apresenta sua fachada principal dividida em cinco partes, sendo um corpo central, dois intermediários e dois laterais. $\bigcirc$ edifício é predominantemente horizontal, simétrico e dispõe os vãos em ritmo regular, características que, associadas ao repertório decorativo, nos permite enquadrá-lo como pertencente ao estilo clássico ${ }^{67}$.

O corpo central, levemente ressaltado, destaca-se devido ao frontão de verga semicircular, que coroa o edifício, com tímpano ornado pelo símbolo da Beneficente Portuguesa. No primeiro pavimento, nota-se a presença de quatro pilastras de capitel dórico, ladeando três vãos em arco pleno, sustentados por pilastras também em linhas dóricas. $\bigcirc$ vão central - a entrada - difere dos demais tendo em vista que não é provido de guarda-corpo trabalhado em ferro em padrão xadrez angulado. Obedecendo ao mesmo ritmo do pavimento de entrada, o segundo pavimento é ornado com quatro pilastras de capitel jônico. Entre elas, abrem-se três vãos retangulares, encimados por frontões triangulares, providos de guarda-corpo em ferro, decorado com motivos geométricos. $\bigcirc$ bloco central apresenta laterais em ligeiro recuo, simétricas entre si, onde abrem-se, no primeiro andar, janelas de peitoril em arco pleno, e no superior, janelas em verga reta ornadas com frontões cimbrados. 
Os corpos laterais são compostos por sete janelas de peitoril de verga reta encimadas por cimalhas decoradas com motivos clássicos, expressos pelas pilastras de capitel dórico que sustentam o vão. Já no pavimento superior, alinhadas às janelas do pavimento abaixo, abrem-se sete janelas de peitoril de verga reta, emolduradas sem ornamentação, as quais se encontram encimadas por frontões triangulares, com exceção da central, a qual está acompanhada de uma cimalha cimbrada. À altura do porão, também dispostos em ritmo regular, abrem-se sete óculos retangulares, importantes para a aeração do edifício.

edifício é fechado nas laterais por dois corpos estreitos que contêm um vão de janela, em arco pleno no primeiro pavimento e em verga reta encimada por frontão cimbrado no superior. Nos pontos centrais dos pavilhões laterais e nos corpos extremos, temos a cimalha ornada com elementos da nacionalidade portuguesa, contendo datas comemorativas.

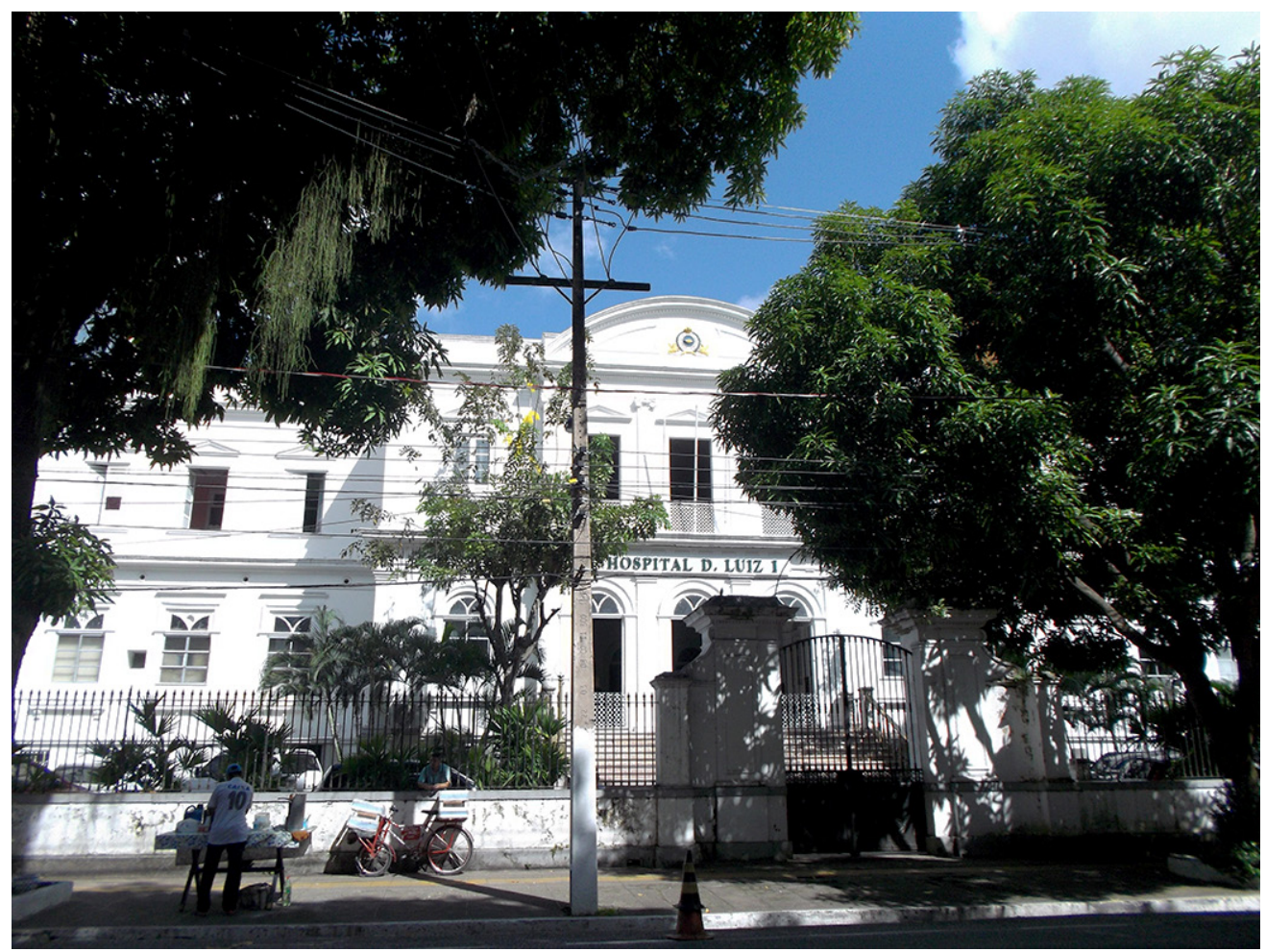

Figura 2 - Fachada principal do Hospital Dom Luiz I, com destaque para seu corpo central. Fotografia de Cybelle Miranda, 2016.

A frontaria é arrematada por platibanda cheia, sendo os pavimentos divididos por cimalha contínua, abaixo da qual, no corpo central, a arquitrave de desenho clássico, obedecendo à ordem dórica das pilastras, apresenta friso com métopas e triglifos. É interessante destacar, ainda, a observância do princípio clássico da sobreposição de ordens, em que as ordens mais rústicas são utilizadas no pavimento térreo e as mais esbeltas nos pavimentos superiores. Ressalta-se, 
68. Joseph Léon Righini (Turim-Itália, ca.1820 - Belém-PA, 1884). Pintor, desenhista, gravador, fotógrafo, cenógrafo, professor. Estudou na Academia de Belas Artes de Turim. Vem para o Brasil por volta de 1856 e fixa-se no Maranhão e no Pará. Em 1867, é publicada por Conrad Wiegandt a série de litografias Panorama do Pará em Doze Vistas desenhadas por J. L. Righini. A obra aqui exposta pertence à Biblioteca Guita e José Mindlin e foi gentilmente cedida ao Centro de Memória da Universidade Federal do Pará. A digitalização das imagens foi feita por Lucia Mindlin Loeb, com apoio da Pró-Reitoria da Administração da UFPA. Disponível em: <http://www.ufpa.br/ $\mathrm{cma}$ /iconografias.html>. Acesso em: 26 out. 2015.

69. Ver Lilia Affonso (2011).

70. Ver História da Benemérita Sociedade Portuguesa Beneficente do Pará, 1974.

71. Em quadro elaborado sobre os professores da Academia, não consta o ano de seu nascimento, apenas o de falecimento, em 1878. Ver Maria Helena Lisboa (2007). porém, que essa ordenação não foi seguida à risca no edifício do Hospital Dom Luiz I, tendo em vista que, influenciado por tendências ecléticas, ele apresenta nos corpos laterais alguns vãos em arco ogival, em contraposição ao pavimento superior, compostos apenas por vãos de verga reta.

Outra característica digna de análise está na alternância entre frontões triangulares e cimbrados notada no pavimento superior, a qual confere aspecto mais elegante em relação ao pavimento inferior, almejando, provavelmente, manter a harmonia da composição da fachada, seguindo, dessa forma, os padrões de seu corpo central, de modo que esse acréscimo se integrasse ao todo, conformando, assim, uma unidade estilística e estética.

A importância do hospital para a configuração oitocentista da metrópole da Amazônia está patente nas imagens de época, com destaque para a pintura do italiano Leon Righini que, na segunda metade do século XIX, pintou vistas de sítios importantes e monumentos da cidade ${ }^{68}$. Dentre eles figura 0 hospital da Beneficente Portuguesa de Belém, do qual avistam-se os corpos laterais apenas com o pavimento térreo, sendo a mesma configuração do postal produzido pela Livraria Universal em finais da centúria, divulgado no Álbum "Belém da Saudade". Segundo Affonso69, o segundo pavimento do bloco principal foi concluído em 1923, para abrigar a ala feminina, porém preocupouse em obedecer com rigor às regras clássicas do projeto, de modo a não deixar perceptível o acréscimo, mantendo o preceito da unidade estilística tão caro a Viollet-le-Duc (Figura 3).

O livro de Artur Vianna ${ }^{70}$ apresenta imagens importantes para a compreensão estratigráfica do monumento, como a foto que demonstra a configuração dos pavilhões paralelos que abrem no flanco esquerdo para o jardim lateral, configuração típica do modelo pavilhonar, alterada radicalmente com a construção do bloco referente à maternidade, em 1960, ainda mantendo as linhas originais do hospital, com a inclusão de entrada lateral com frontão cimbrado (Figuras 4 e 5).

A importância desse monumento para a colônia portuguesa é evidenciada com a publicação do Álbum da Colônia Portuguesa no Brasil, em 1929, que ainda confere destaque à Sociedade Portugueza Beneficente do Pará, enfatizando seus diretores e o Hospital D. Luiz I (Figura 6).

O Hospital de Alienados do Conde de Ferreira da Santa Casa de Misericórdia do Porto e o Engenheiro Manuel de Almeida Ribeiro

Formado na Academia Politécnica do Porto em 1854, Manuel de Almeida Ribeiro foi responsável pelas cadeiras de desenho no Liceu Nacional do Porto e proprietário da Aula de Arquitectura civil (nomeado após concurso) entre 1865 e 187871. Não teve outros cargos acadêmicos.

No livro de Maria Helena Lisboa, o professor é citado pela primeira vez quando do texto da Reforma da Academia, de 1875, sendo atribuída a ele a 


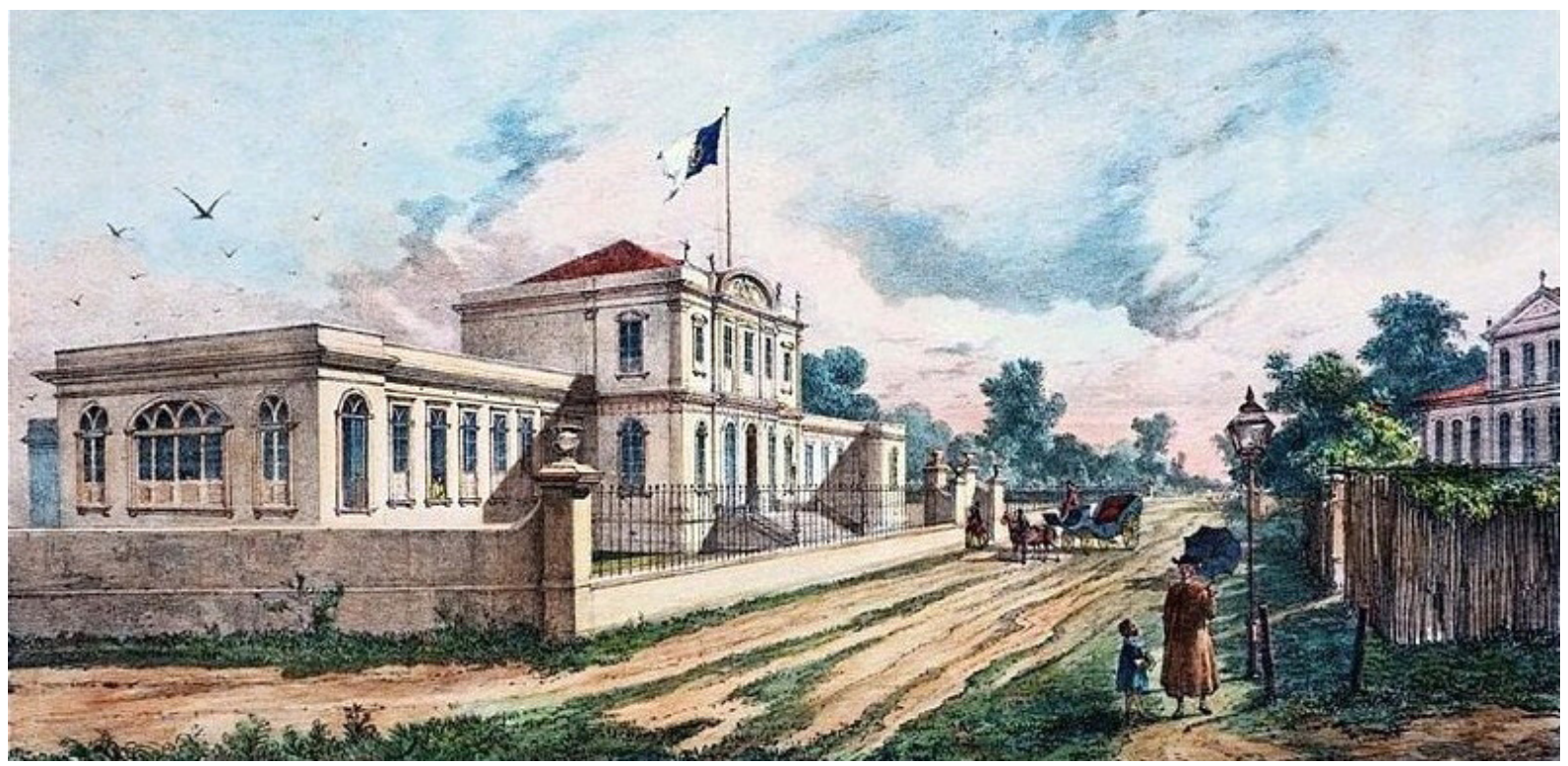

Figura 3 - Hospital da Beneficente Portuguesa de Belém, de Joseph. Léon Righini, 1867. Biblioteca Guita e José Mindlin. Centro de Memória da Universidade Federal do Pará.

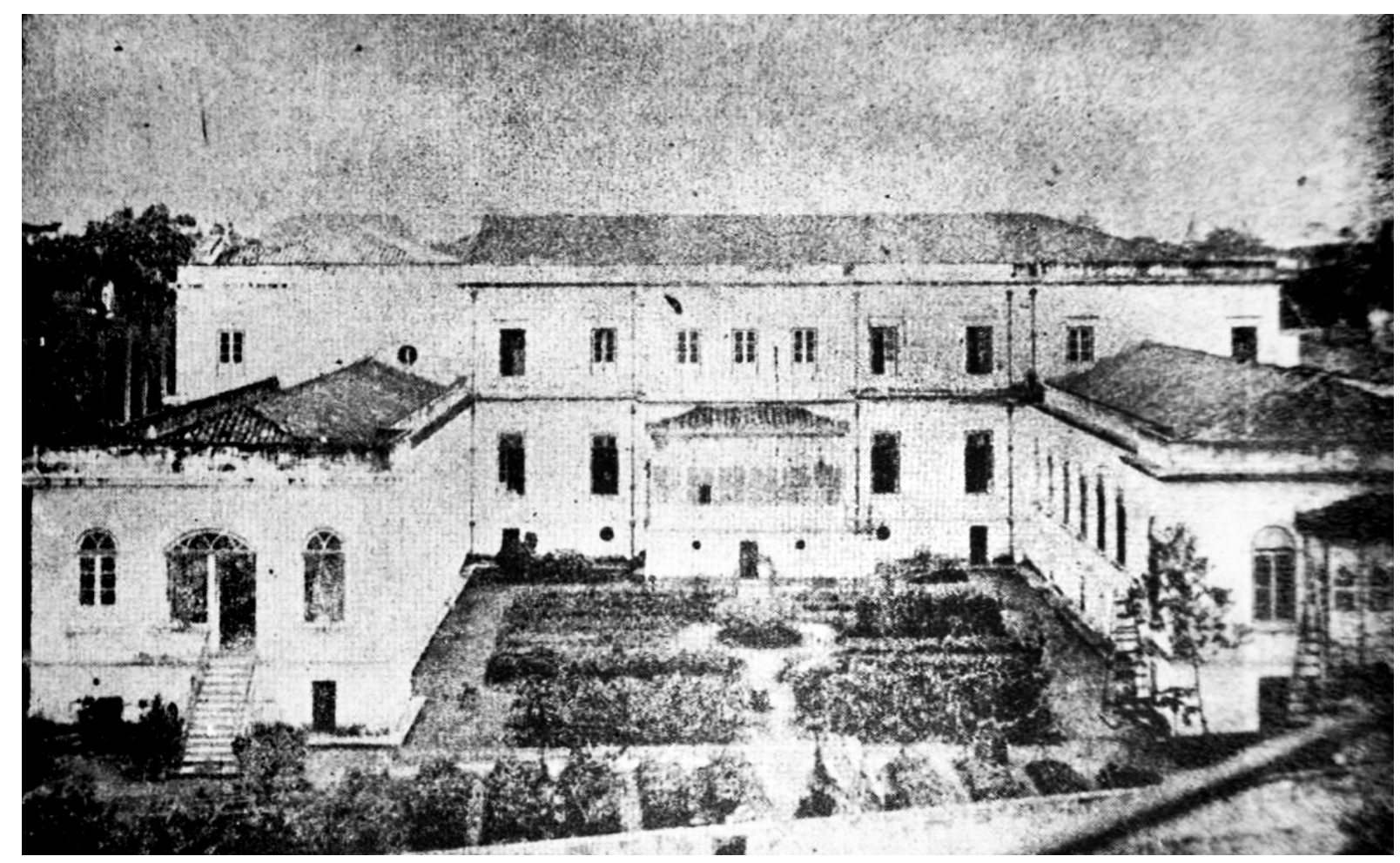

Figura 4 - Vista lateral do hospital da Beneficente Portuguesa de Belém pela Travessa Boaventura da Silva, sem data. História da Benemérita Sociedade Portuguesa Beneficente do Pará, 1974. 
72. Cf. João Maria Távora de Magalhães Basto (2012, p. 44).

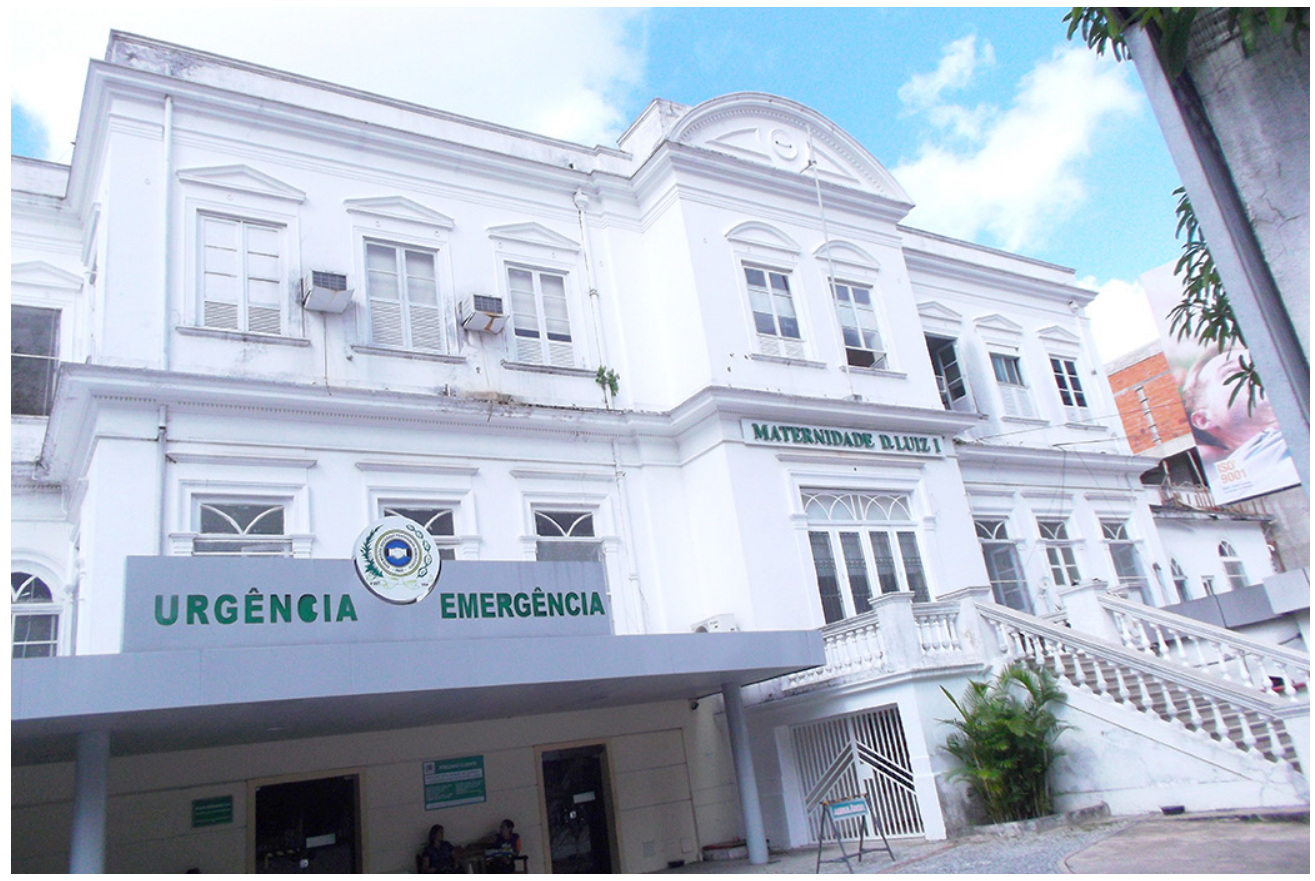

Figura 5 - Bloco da maternidade edificado na lateral da Travessa Boaventura da Silva. Fotografia de Cybelle Miranda, 2016.

concepção do plano referente ao Curso de Arquitetura, já que se tratava do único professor da cadeira. $\bigcirc$ conteúdo das mudanças propostas, mas não efetivadas, consistia na exigência de aprovação nas cadeiras do curso de desenho para então passar ao curso especial de Arquitetura, que deveria conter cadeiras científicas a serem cursadas no Instituto Industrial do Porto, tais como Geometria descritiva aplicada à indústria, Estereotomia e Topografia; Física e suas aplicações à arte; Química aplicada às artes e à indústria, Mecânica industrial, Construções civis e Tecnologia geral.

Em 23 de janeiro de 1865 "é nomeado para a regência interina desta cadeira um engenheiro de pontes e estradas, antigo aluno da Academia e professor de desenho linear do liceu nacional, Manuel de Almeida Ribeiro"72.

João Maria Távora de Magalhães Basto deduz que Manuel de Almeida Ribeiro não tivera muita experiência no estrangeiro, sendo detectada uma visita a Paris em 1859, quando the foi solicitado pela Academia Politécnica de ali adquirir instrumentos e máquinas para a dita instituição, com verba alocada pelo governo português. Pode-se inferir, portanto, que os conhecimentos adquiridos por Manuel Ribeiro restringiam-se a sua formação como engenheiro e ao repertório de imagens disponíveis na cidade do Porto no século XIX.

Submeteu-se a concurso para professor proprietário da aula de Arquitetura no verão de 1865. Nesse certame concorreram com ele um alferes, António Vasco da Gama Braga, e José Maria Correia da Silva, sendo o nome de Manuel Ribeiro anunciado como vencedor 
pela superioridade demonstrada nas três provas que tiveram que defender, que aliás nos parece interessante descrever: na primeira prova dispunham de três dias para a resolução dum problema de Geometria. A segunda prova era dedicada ao Esboço de um edifício e era dividida em 3 sessões: na $1^{a}$ desenhavam-se as plantas; na $2^{a}$ os alçados e na $3^{a}$ secções. E, por fim, a $3^{a}$ prova era dedicada ao projecto de um navio: durante 30 dias, a uma escala escolhida pelo jury, tinham que apresentar alçados, plantas e secções principais duma embarcação. Todos estes exercícios tinham que ser acompanhados duma memória descritiva escripta pelos concorrentes no preciso espaço de oito horas dentro do edifício da Academia ${ }^{73}$.

Dentre os trabalhos técnicos realizados por Almeida Ribeiro, que terminara o curso de Engenharia de Pontes e Estradas na Academia Politécnica, mas deixara incompleto o de Arquitetura, consta a planta do Hospital do Conde

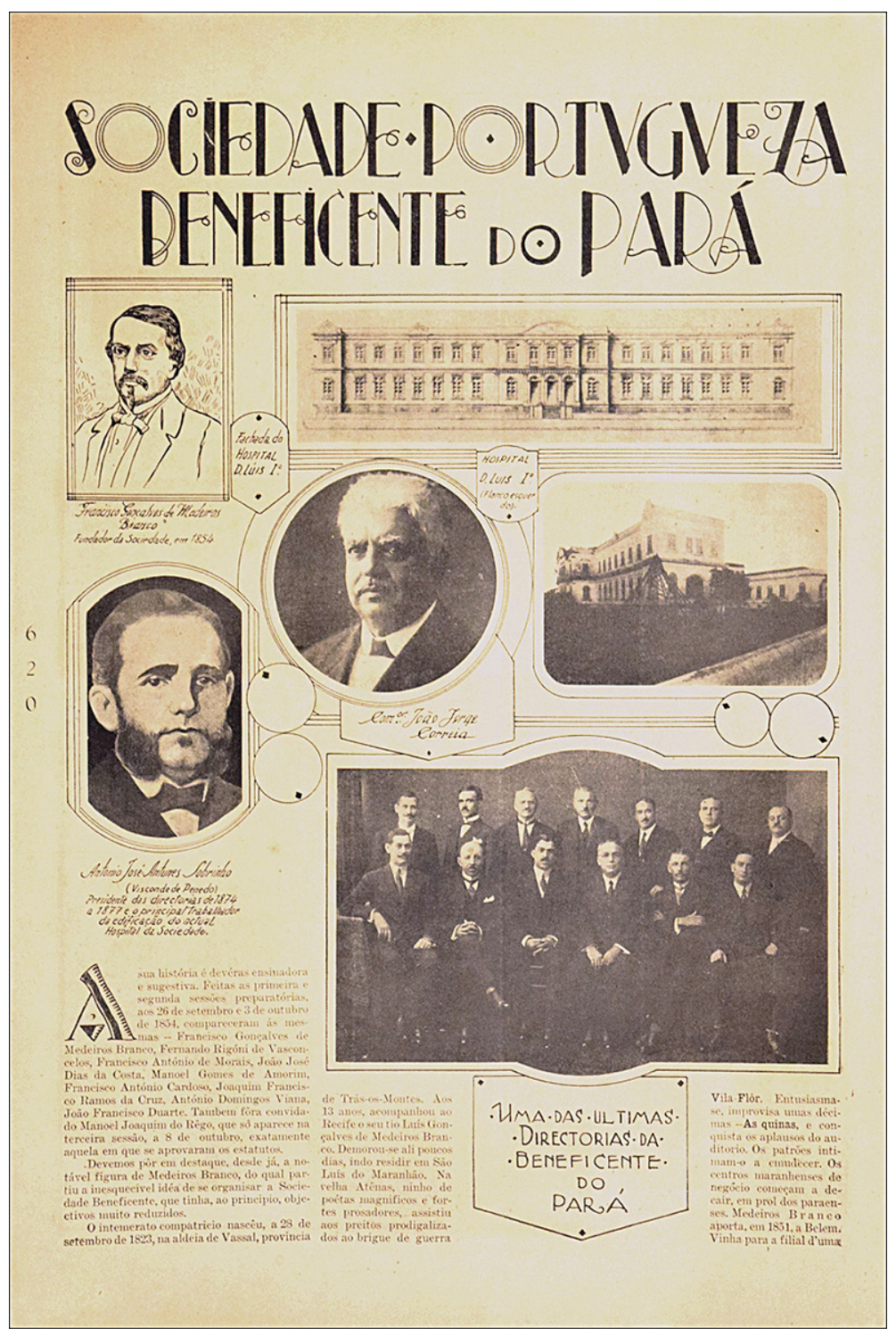

Figura 6 - Capa do Álbum da Colônia Portuguesa no Brasil, 1929. Disponível em: www.ufpadoispontozero.com.br. Acesso em: 10 de ago. 2015.
73. Cf. João Maria Távora de Magalhães Basto (2012 p. 45 , grifos do autor). 
74. Cf. João Maria Távora de Magalhães Basto (2012. p. 48).

75. Cf. João Maria Távora de Magalhães Basto (2012, p. 48).

76. Ver Fernando Carvalho, António Santos Rocha, Deolinda Lopes, José Rocha, João Teles e Maria José Figueiredo Silva (1996).

77. Ver João Maria Távora de Magalhães Basto (2012).

78. Ver Pedro Teixeira Pereira, Eva Gomes, Olga Martins (2005).

79. Em 1861, criou-se no Porto a Sociedade do Palácio Agrícola, que adquiriu os terrenos dos campos da Torre da Marca para lá edificar o Palácio de Cristal. D. Pedro V foi o primeiro subscritor para a construção do palácio, sendo o projeto do edifício elaborado pelo arquiteto inglês Thomas Dillen Jones. (D. Pedro V morreu em 1861 e foi sucedido por D. Luis I). Porém o projeto foi alterado e passou a contar com corpos em granito, tradição do Norte de Portugal. Do Júri de Belas Artes que organizou a exposição consta Manuel de Almeida Ribeiro, autor do projeto do Hospital do Conde de Ferreira. Ver José Coelho dos Santos (1989).

80. Ver José Coelho dos Santos (1989). de Ferreira, primeiro hospital feito de raiz em Portugal, para doentes psiquiátricos. Em 1866, apresentou na Exposição Trienal da Academia um Hospital de alienados mandado fundar por disposição testamentária do Conde de Ferreira: dous quadros (...), e que seriam já desenhos para o futuro hospital74.

Outro trabalho por ele concebido foi o levantamento topográfico para a cidade de Guimarães em conjunto com um Plano de Melhoramentos solicitado, em outubro de 1863, pela autarquia da cidade. Entregue apenas em 1867, era composto pela alocação de um bairro operário, a localização de escolas primárias e a abertura de quatro novas praças. Essa proposta foi a base para os projetos implantados na cidade até o início do século XX. Na 10 Exposição Trienal da Academia Portuense, que ocorreu em outubro de 1869, enquanto professor proprietário da aula de Arquitetura Civil, apresentou um Edifício para as repartições públicas da cidade de Guimarães, plantas, corte e alçado, que obviamente veio na continuidade daquela encomenda da Planta da Cidade de Guimarães. Para a trienal seguinte, a $11^{a}$, que só viria a público em 1874 em consequência da recorrente falta de condições nas instalações do edifício de S. Lázaro, o Professor Manuel de Almeida Ribeiro expôs projetos de escolas primárias ${ }^{75}$.

Almeida Ribeiro foi professor durante treze anos, até seu falecimento, aos 45 anos. Após sua morte, foi substituído por José Geraldo Sardinha, que fora pensionista do Estado em Paris entre 1867 e 1873.

Segundo Fernando Carvalho et al., no início do século XIX, Portugal encontrava-se profundamente atrasado em relação aos demais países da Europa, no diagnóstico e no tratamento de seus alienados ${ }^{76}$. Em 1866, como já mencionado neste artigo, o falecimento do Conde de Ferreira resultou no testamento que destinou uma vultosa soma para a edificação de raiz de um hospital de alienados, na cidade do Porto. O hospital seria dependente da Santa Casa de Misericórdia do Porto, porém com caráter autônomo e privado, uma vez que a Misericórdia se eximia de qualquer responsabilidade financeira perante 0 estabelecimento. Inaugurado em 1883, 15 anos depois do início das obras em 1868, então recebeu os primeiros internos. $\bigcirc$ projeto, elaborado por Manuel de Almeida Ribeiro, fora modificado durante a construção, sob a orientação do Diretor de Obras Públicas do Distrito do Porto, Faustino José da Vitória77.

Segundo o testamento, o edifício deveria ser executado com perfeição e solidez, sendo construído a nordeste da cidade, no local da Cruz das Regateiras, sendo a arquitetura inspirada no Hospício Pedro II, inaugurado em 1852, no Rio de Janeiro. Na fachada, a estátua do Conde de Ferreira sobressaía, e o prédio foi implantado em um terreno de 120 mil metros quadrados, com áreas livres para jardins e plantações ${ }^{78}$.

O Hospital do Conde de Ferreira se inclui no contexto de outras obras executadas no Porto, como o Palácio de Cristal, inaugurado em 1865 quando da organização da Exposição Internacional da Indústria ${ }^{79}$. O período da Regeneração em Portugal está ligado à introdução do capitalismo industrial e ao Ministro da Fazenda e das Obras Públicas, Fontes Pereira de Melo ${ }^{80 .}$ 
No livro Hospital do Conde de Ferreira - Breve História ${ }^{81}$ são relatadas as intenções do benemérito Conde de Ferreira ao determinar a construção do primeiro hospital de raiz para o tratamento de doentes mentais em Portugal. A escolha do terreno deveria ter em conta sua extensão, para que pudesse conter amplos jardins, prados e terras para cultivar, além de boa exposição higiênica. A encomenda do projeto a Almeida Ribeiro deveu-se, segundo o texto, à amizade entre ele e o conde, e o plano foi elaborado com base em relatórios de ministros portugueses no estrangeiro. A inspiração está registrada no retrato do conde, afixado no salão nobre da instituição, no qual ele é representado de corpo inteiro, tendo o hospital carioca como fundo. A construção arrastou-se por 10 anos e após seu falecimento, o engenheiro foi sucedido por Faustino José da Vitória, que realizou alterações no projeto, como, por exemplo, o deslocamento da escadaria principal para a lateral, com caráter interno ${ }^{82}$.

"A planta era dividida em ala norte para doentes do sexo masculino, ala sul para doentes femininos, e corpo central para serviços gerais, gabinete do diretor, casa de aceitação e laboratório de Antropologia, totalizando 14 enfermarias" 83 . 0 laboratório de Antropologia é sinal do avanço do tratamento no hospital.

Os doentes, com exceção dos indigentes, pagavam mensalidades de acordo com as classes sociais em que se enquadravam e recebiam diferentes comodidades conforme o pagamento. Porém, segundo os autores,

todas as enfermarias tinham em comum o facto de, além de serem amplas e iluminadas, terem em atenção dois dos indicadores das preocupações higienistas de Oitocentos: a ventilação e a água. Estas encontravam-se ainda equipadas com espaços de lazer (salas de recreio, jardins e parques ${ }^{84}$

As remodelações que o hospital sofreu entre 1883 e 1908 resultam de problemas de manutenção; e entre 1887 e 1888 foi construído um pavilhão de dois andares com ambientes para moradia do diretor e médico adjunto, além de habitações para funcionários, que até então habitavam as mesmas alas dos doentes. Em 18901891, foram construídas células de isolamentos para alienados agitados, pois as 28 existentes eram insuficientes para a população de 397 internos. Os autores concluem que o Hospital do Conde de Ferreira foi pioneiro na implantação de técnicas modernas de tratamento, em contraposição ao hospital lisboeta de Rilhafoles, adotando altos padrões científicos e a polífica higienista, com pavilhões iluminados.

Em 1886, foi construído em frente ao edifício um hospital barraca para isolamento de doentes contagiosos, e em 1890 ergueram-se dois pavilhões para doentes furiosos. Em 1904, foi acrescido o edifício para criminosos, depois ocupado por crianças e tuberculosos, e em 1907, o edifício para doentes agitados $^{85}$ (Figura 7). Costa ${ }^{86}$ atesta a adoção dos modelos prisionais, notadamente o panótico de Bentham, nos espaços de isolamento para alienados, modelo que vemos no Hospital de Alienados no Porto, espaço hoje ocupado como parte do contexto museológico. $\bigcirc$ partido adota celas radiais com portas de ferro e circulação superior de vigilância.
81. Ver Fernando Carvalho, António Santos Rocha, Deolinda Lopes, José Rocha, João Teles e Maria José Figueiredo Silva (1996).

82. Ver Fernando Carvalho, António Santos Rocha, Deolinda Lopes, José Rocha, João Teles e Maria José Figueiredo Silva (1996).

83. Cf. Pedro Teixeira Pereira, Eva Gomes, Olga Martins (2005. p. 101).

84. Cf. Pedro Teixeira Pereira, Eva Gomes, Olga Martins (2005. p. 101).

85. Ver Fernando Carvalho, António Santos Rocha, Deolinda Lopes, José Rocha, João Teles e Maria José Figueiredo Silva (1996).

86. Ver Renato da Gama-Rosa Costa (2008, p. 122). 
87. Cf. Legrand du Saulle apud Pedro Teixeira Pereira, Eva Gomes, Olga Martins (2005, p. 102).

88. Maior horta social da Europa é no Porto. Disponível em: http://www.porto. pt/imprensa/maior-horta-social-da-europa. Postado em: 24 de março de 2015. Acesso em: 18 jul 2016.

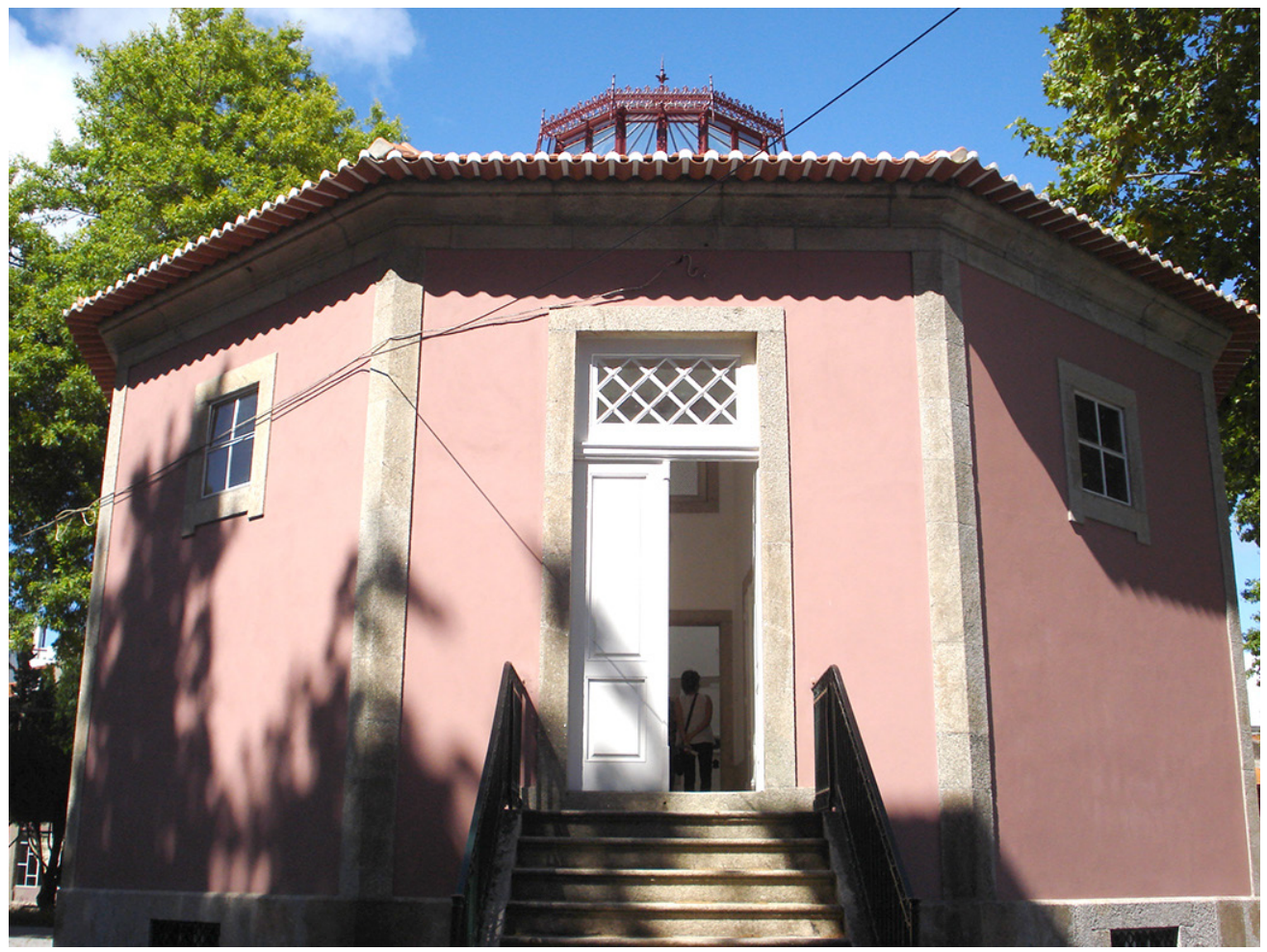

Figura 7 - Panótico utilizado para abrigar doentes criminosos. Fotografia de Cybelle Miranda, 2013.

hospital portuense foi pioneiro ao empreender medidas profiláticas de higiene, diretriz priorizada por diretores como António Maria de Senna. A construção recebeu alterações, como a instalação de um gabinete fotográfico em 1888-1889, recurso utilizado em hospitais estrangeiros, visto que "[a] arte fotográfica veio facilitar o registro das expressões patológicas tão relevantes no estudo da alienação mental"87.

hospital mantinha entre seus procedimentos a conscientização das famílias acerca da doença, o que era feito em domicílio pelos médicos assistentes. Contudo, isso não se refletia na frequência das famílias em visitas aos doentes, sendo muitos abandonados na instituição. Por outro lado, o impacto da construção do edifício hospitalar fez-se sentir pelo afluxo de visitantes ao nosocômio, que se tornou um passeio de fim de semana dos portuenses, decorrência também do tratamento do paisagismo fronteiro do lote e a utilização do amplo terreno posterior como horta - designada em 2015 como a maior horta social da Europa ${ }^{88}$. Essa preocupação com os espaços verdes fez parte da concepção original do hospital, como se percebe na planta publicada no livro Os alienados em Portugal II Hospital Conde de Ferreira, escrito pelo médico António Maria de Senna (Figura 8).

A questão higienista impregnou a prática do hospital, sendo o Conde de Ferreira o primeiro da especialidade a acompanhar essa tendência, baseando- 
se no cuidado com a água e a alimentação. Os desenhos do hospital indicam a existência de 10 refeitórios, 4 destinados às $1^{a}$ e $2^{a}$ classes e 6 a $3^{a}$ classe;

os planos de construção dos refeitórios dos alienados tranquilos tiveram a consideração de os tornar espaços acolhedores e familiares, distintos dos comuns, unicamente pelo facto de as cadeiras estarem unidas por uma trave de madeira. Os refeitórios dos agitados diferiam dos anteriores, na medida em que tendiam a ser mais seguros e robustos, sendo a mobília aparafusada ao chão ${ }^{89}$.

edifício do Hospital Conde de Ferreira possui dois pavimentos, separados por uma cornija saliente, mais porão, e sua fachada está tripartida sendo uma parte central e duas laterais (Figura 9).

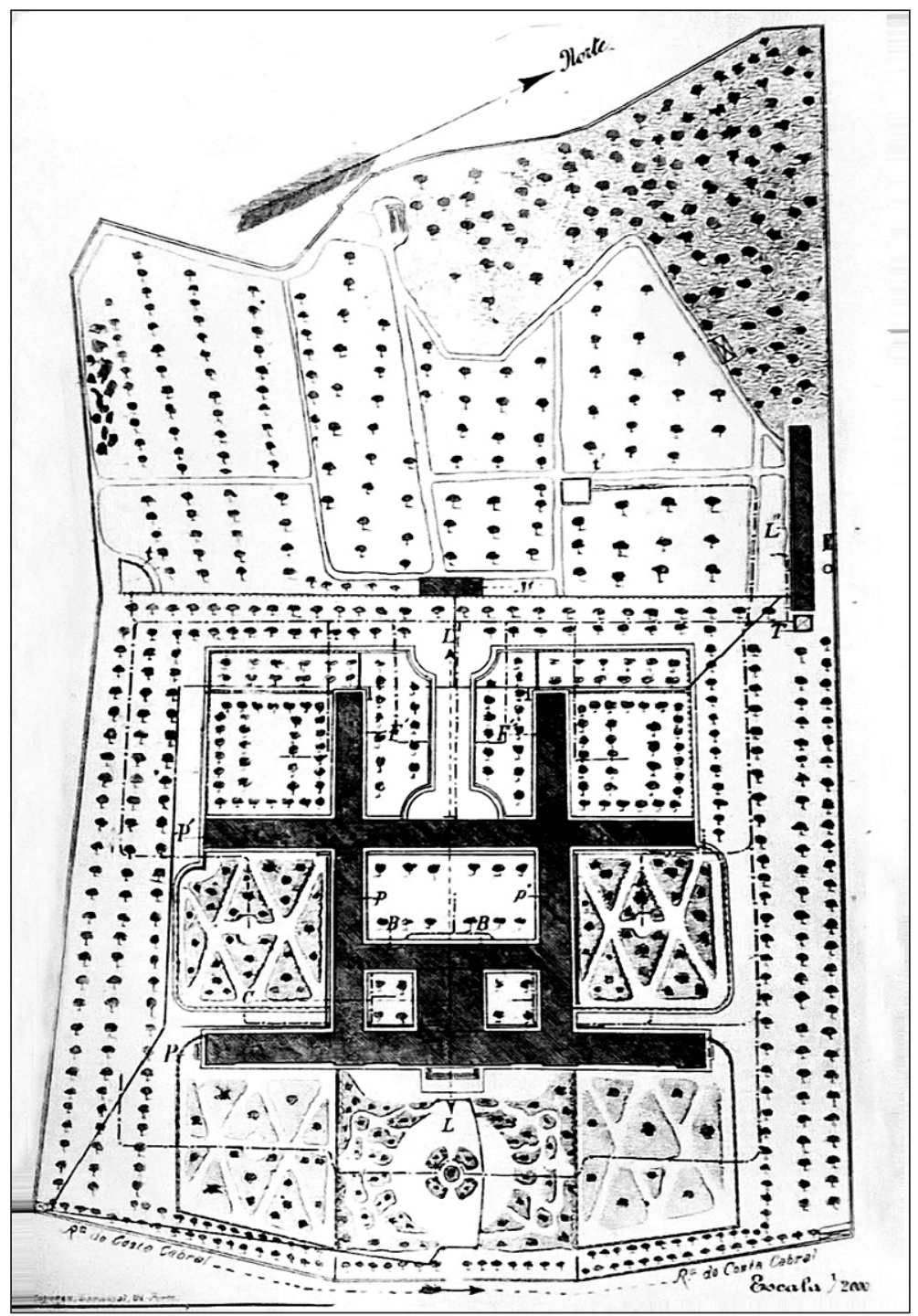

Figura 8 - Planta do terreno do hospital com desenho paisagístico. Os alienados em Portugal II Hospital do Conde de Ferreira, de António Maria de Senna, 1995.
89. Cf. Pedro Teixeira Pereira, Eva Gomes, Olga Martins (2005, p. 103). 
A parte central distingue-se do restante do corpo por ser toda em pedra e por estar assentada em relevo. No primeiro pavimento, abrem-se três arcos de volta perfeita, assentes em pilastras de capitel dórico e coroadas por uma bandeira em leque fixa, que dão acesso a um átrio. Entre os arcos, há quatro pilastras de capitel dórico, providas de pedestal simples. No pavimento superior, abrem-se três janelas de peitoril em arco pleno, arrematadas por chave. Os vãos das esquadrias estão assentes sobre pilastras dóricas e enquadrados por vãos retangulares. $\bigcirc$ corpo de acesso é marcado nas extremidades por pilastras rusticadas encimadas por vasos-fogaréus e arrematado por frontão triangular em cujo centro enquadra-se um relógio festonado.

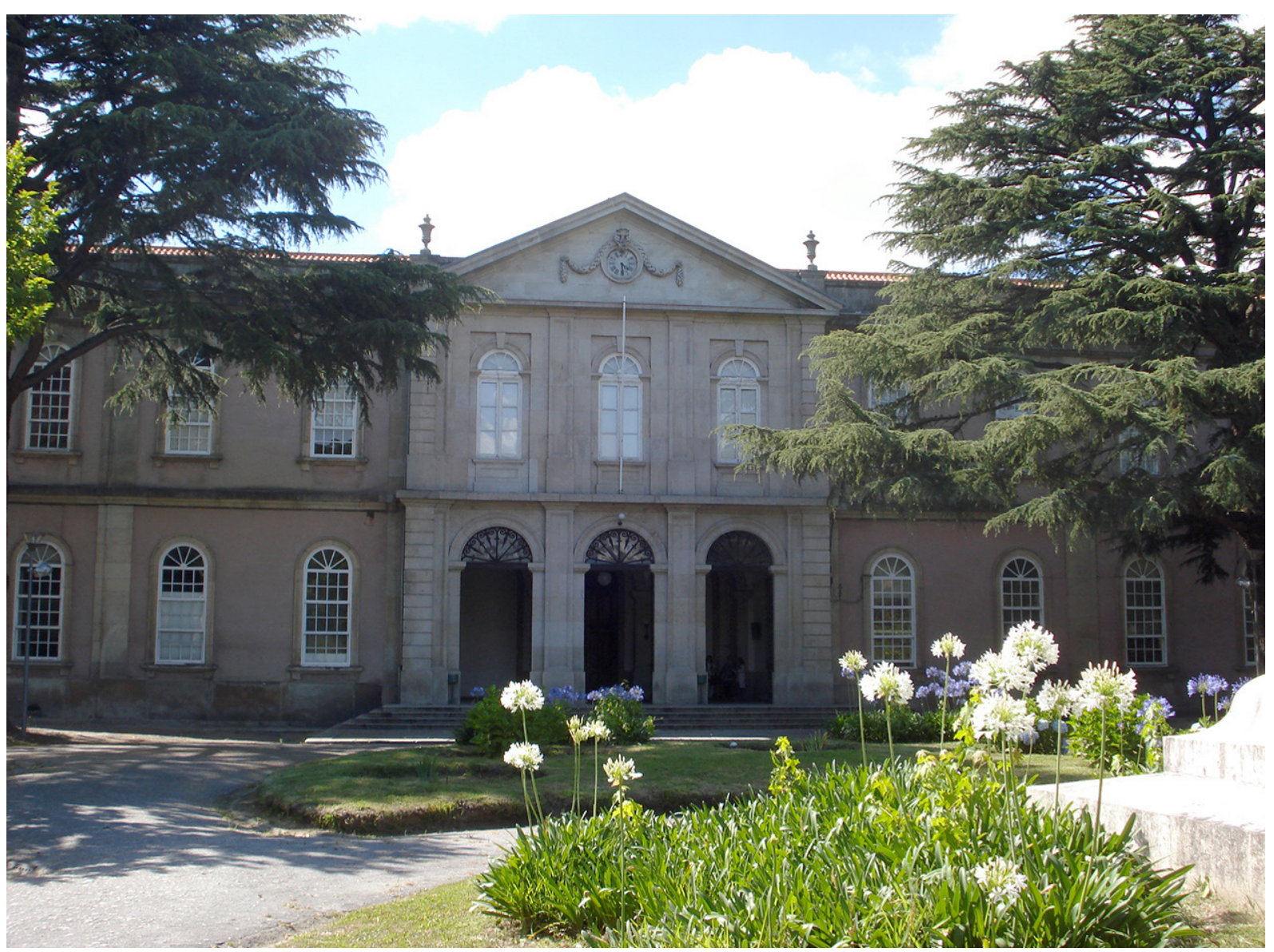

Figura 9 - Fachada principal do Hospital Conde de Ferreira. Fotografia de Cybelle Miranda, 2012

Em relação às partes laterais, idênticas, é possível notar a horizontalidade dessas porções, o que dá o caráter monumental à obra. Abre-se nos dois pavimentos uma série de janelas de guilhotina de peitoril, com verga em arco de volta perfeita, em ritmo regular, contornadas por uma moldura simples que segue o mesmo formato do vão. Arrematando o edifício neoclássico, nota-se um friso denticular encimado por uma platibanda cheia. 
Os corpos laterais são bastante extensos, ritmando as esquadrias em módulos de duas e quatro janelas, demarcadas por pilastras, sendo que o pavilhão principal é composto pelo corpo central e corpos laterais contando com oito vão cada acrescido de dois vão extremos marcados por pilastras e platibanda balaustrada. Esses corpos fazem ligação com dois pavilhões que ampliam consideravelmente a fachada em mais nove vãos em cada lado, sendo a fachada composta por 41 vãos em cada um dos dois pavimentos (Figura 10).

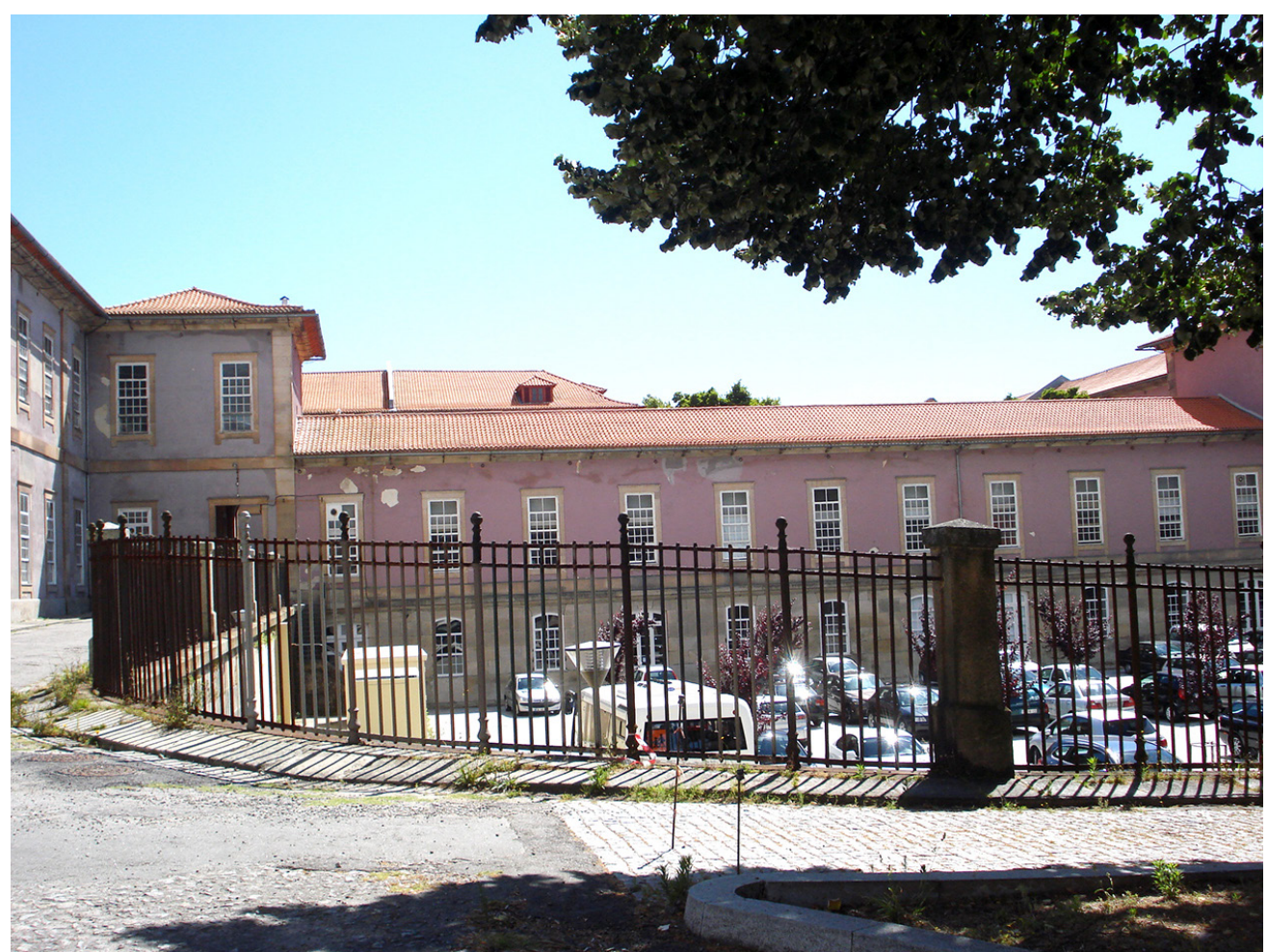

Figura 10 - Vista da lateral esquerda, bloco posterior, que demonstra a adaptação do edifício à topografia do terreno. Fotografia de Cybelle Miranda, 2013.

Do acervo iconográfico da Misericórdia do Porto, disponível no Portal do Arquivo Municipal do Porto, encontramos dez imagens antigas do Hospital do Conde, o que já em si revela sua importância e amplia a possibilidade de análise do edifício. Destacamos o postal de 1900, em que se vê a estátua do Conde de Ferreira no topo do frontão, e no seguinte, datado de 1907, em que a escultura foi deslocada para pedestal ao centro do jardim, tendo o chafariz que ocupava o mesmo sítio sido transferido para área lateral do hospital. A imagem de 1907 destaca a imponência do benemérito fundador, permitindo vislumbrar trecho da fachada em que as marcações com pilastras ao modo de cunhais pombalinos apenas modulam uma planimetria sem ondulações ${ }^{90}$.

Em gravura de 1883, o Hospital de Alienados do Conde de Ferreira aparece mostrando o edifício e os terrenos envolventes após a inauguração. $\bigcirc$
90. Ver Porto: Hospital de Alienados do Conde Ferreira. Documento/Processo, [1900] - [1900]. (Série: geral, $\left.n^{\circ} 8\right)$. Arquivo Municipal do Porto; Porto: Hospital de Alienados do Conde de Ferreira. Documento/ Processo, [1907] - [1907]. (Série: geral, $\mathrm{n}^{\circ} 8 \mathrm{a}$ ). Arquivo Municipal do Porto. 
91. Ver Hospital de Alienados do Conde de Ferreira: inaugurado em 21 de março de 1883. Documento/Processo, [1985] - [1985]. Gravura representando uma perspectiva do Hospital do Conde de Ferreira e dos terrenos envolventes, após a inauguração. Trata-se da reprodução de uma gravura, a partir de fotografia de Silva Pereira e Ferreira, publicada na revista $O$ Occidente, em 1883. Arquivo Municipal do Porto. contexto rural da zona aparece nas pessoas, bem como na aridez da paisagem, e o partido pavilhonar destaca-se na lateral em primeiro plano91.

Desdobramentos estéticos do ensino de Arquitetura nos edifícios hospitalares D. Luiz I e Conde de Ferreira

Conclui-se que, devido às diversas vicissitudes por que passaram as academias portuguesas, desde sua fundação na primeira metade do século XIX até princípio do século XX, a formação dos arquitetos não era completa, sendo desenvolvida uma base inicial compartilhada para todas as artes Pintura, Escultura ou Arquitetura -, que deveria ser especializada nos ateliers dos mestres em Portugal ou no estrangeiro - na maior parte das vezes em Paris. Por isso, os que cursavam apenas as aulas da academia, ao longo de quase todo o século XIX, não recebiam diploma de arquiteto. Nota-se claramente a defasagem entre os desenhos iniciais desenvolvidos por discentes das academias e as obras dos pensionistas no estrangeiro, tanto em Lisboa quanto no Porto. Considerando percentual extremamente reduzido de candidatos selecionados para receber o apoio do governo, a formação em Arquitetura muitas vezes resumia-se às aulas da academia que, nas primeiras décadas, continha mínimo conteúdo teórico. A emulação era a base para a medição do progresso dos discentes, submetidos aos concursos trienais posteriormente anuais.

Podemos depreender da análise preliminar dos hospitais em questão a evidente diferença entre o programa decorativo de fachada do hospital D. Luiz l em relação ao hospital do Conde de Ferreira, uma vez que o primeiro apresenta repertório marcado por maior erudição e preocupação com os signos identitários da nacionalidade portuguesa como a esfera armilar, os elos de corrente, o dragão, bem como o emprego do formulário clássico nas colunas, pilastras e nas molduras dos vãos. Outro aspecto a destacar é a movimentação do volume da fachada de Belém, cujos planos alternam-se, produzindo um edifício que se afasta da monotonia mais comum do repertório do classicismo imperial e que se pode notar na frontaria do Hospital do Conde de Ferreira, no Porto. A extensão alongada da fachada absolutamente plana, lembrando ainda vagamente o maneirismo português, bem como a coloração dada pelo cinza granilítico portuense, conferem um ar mais sóbrio e austero ao hospital portuense, o qual internamente apresenta decoração pouco profusa, até mesmo na capela que, a despeito da alocação central com acesso pelo átrio de entrada, não possui configuração arquitetônica que enobreça sua função, assinalada apenas pelos altares neoclássicos em branco e dourado.

Da análise dos objetos arquitetônicos podemos depreender as respectivas formações e influências de seus projetistas: maior elegância e erudição conferidas ao Hospital da Benemérita Sociedade Portuguesa 
Beneficente do Pará e o aprendizado calcado no desenho das ordens arquitetônicas e nas lições de Vinhola; e o projeto do Hospital Psiquiátrico da Misericórdia do Porto, que revela linhas sóbrias e funcionais, solidez e monumentalidade pela extensão das alas, as quais proporcionam arejamento por meio dos pátios internos generosos e áreas de entorno ajardinadas. $\bigcirc$ imperativo funcional é contrabalançado pela estátua do benemérito fundador, - Conde de Ferreira, concebida pelo escultor Soares dos Reis, que inicialmente ornava o cume do frontão triangular, e alguns anos mais tarde passa a ocupar - canteiro central da entrada, uma vez que suas dimensões são desproporcionais para o uso em frontaria. 


\section{REFERÊNCIAS}

\section{DOCUMENTAÇÃO PRIMÁRIA}

\section{Manuscritas}

Faculdade de Belas-Artes. Universidade de Lisboa.

Livro de Matrículas (1842-1850. p. 100).

\section{Impressas}

AFFONSO, Lilia. Benemérita Sociedade Portuguesa Beneficente do Pará: 1854-2010. Belém: Gráfica Sagrada Família, 2011.

Belém da Saudade: a memória da Belém do início do século em Cartões Postais. Belém: Secult, 2004.

CARVAlHO, Fernando et. al. Hospital do Conde de Ferreira - Breve História. Porto: Hospital do Conde de Ferreira, 1996.

História da Benemérita Sociedade Portuguesa Beneficente do Pará. Ampliação do resumo escrito por Arthur Vianna em 1904 no Jornal do Comércio. Belém: s.n.,1974.

Revista Universal Lisbonense $2^{\mathrm{a}}$ série Tomo V, $\mathrm{n}^{\circ} 26$ de 5 de janeiro de 1853. Disponível em: http://hemerotecadigital.cm-lisboa.pt/OBRAS/RUL/1852-1853/1852-1853.htm

Revista Universal Lisbonense $2^{\mathrm{a}}$ série Tomo V, $\mathrm{n}^{\mathrm{o}} 32$ de 17 de fevereiro de 1853. Disponível em: http://hemerotecadigital.cm-lisboa.pt/OBRAS/RUL/1852-1853/1852-1853.htm

SENNA, António Maria de. Os alienados em Portugal II Hospital do Conde de Ferreira. Porto: Imprensa Portuguesa, 1885.

\section{LIVROS, ARTIGOS E DISSERTAÇÕES}

ANACLETO, Regina. Arquitectura Neomanuelina no Brasil: a saudade da Pátria. Camões Revista de Letras e Culturas Lusófonas, Lisboa, n. 11, p. 38-51, out/dez 2000 (Pontes Lusófonas III Arquiteturas luso-brasileiras). 
BASTO, João Maria Távora de Magalhães. José Geraldo da Silva Sardinha (1845-1906) para a Academia Portuense de Belas Artes, 2012. 180 f. Dissertação (Mestrado em História da Arte Portuguesa) - Departamento de Ciências e Técnicas de Património, Faculdade de Letras, Universidade do Porto, 2012.

BELTRÃO, Jane Felipe. Memórias da cólera no Pará (1855 e 1991): tragédias se repetem? História, Ciências Saúde-Manguinhos, Rio de Janeiro, v. 14, suplemento, p. 145-167, 2007.

COSTA, Magda Nazaré Pereira da. Caridade e Saúde pública em tempo de epidemias. Belém 1850-1890. 2006. 108 f. Dissertação (Mestrado em História) - Centro de Filosofia e Ciências Humanas, Universidade Federal do Pará, Belém, 2006.

COSTA, Renato da Gama-Rosa. Arquitetura e Saúde no Rio de Janeiro. In: PORTO, Ângela et. al. História da saúde no Rio de Janeiro: instituições e patrimônio arquitetônico. Rio de Janeiro: Ed. FIOCRUZ, 2008, p. 15-28.

DERENJI, Jussara. Arquitetura Eclética no Pará no período correspondente ao ciclo econômico da borracha: 1870-1912 In: FABRIS, Annateresa. Ecletismo na Arquitetura Brasileira. São Paulo: Nobel, Edusp, 1987.

DERENJI, Jussara. Arquitetura nortista: a presença italiana no início do século XX. Manaus: SEC, 1998.

FARIA, Alberto Claudio Rodrigues. A Colecção de Desenho Antigo da Faculdade de Belas-Artes de Lisboa (1830-1935): tradição, formação e gosto. 2008. 373 f. Dissertação (Mestrado em Museologia e Museografia) - Faculdade de Belas-Artes, Universidade de Lisboa, 2008. v. 1.

FERREIRA-ALVES, Joaquim Jaime B. Ensaio sobre a arquitectura barroca e neoclássica a Norte da bacia do Douro. Ciências e Técnicas do Património - Revista da Faculdade de Letras, Porto, S. 1, v. 4, p. 135-153, 2005.

FIGUEIREDO, Aldrin Moura de. Portugueses, italianos e franceses nos círculos artísticos de Belém do Pará (1880-1920) In: ARRUDA, José Jobson de Andrade et al (Org.). De colonos a imigrantes: i(e)migração portuguesa para o Brasil. São Paulo: Alameda, 2013, v. 1, p. 549-561.

FIGUEIREDO, Cibelly Alessandra Rodrigues. Hospital D. Luiz I da Benemérita Sociedade Portuguesa Beneficente do Pará como documento/monumento. 2015. 156 f. Dissertação (Mestrado em Arquitetura e Urbanismo) -- Faculdade de Arquitetura e Urbanismo, Universidade Federal do Pará, Belém, 2015.

FRANÇA, José-Augusto. A Arte Portuguesa de Oitocentos. Lisboa: Instituto de Cultura e Língua Portuguesa, 1992. (Biblioteca Breve v. 28) 
GEERTZ, Clifford. A interpretação das Culturas. Rio de Janeiro: Zahar Editores, 1978.

GINZBURG, Carlo. Mitos, emblemas, sinais - morfologia e história. São Paulo: Companhia das Letras, 1989.

GOMES, Paulo Varela. Expressões do Neoclássico. Lisboa: Fubu Editores, 2009. (Coleção Arte Portuguesa da Pré-história ao século XX).

LE GOFF, Jacques. História e Memória. Campinas: Editora da Unicamp, 2003.

LISBOA, Maria Helena. As Academias e Escolas de Belas Artes e o Ensino Artístico (1836-1910). Lisboa: Colibri, 2007.

MARTINS, Ismênia de Lima. Imigração, inserção social e urbanização. Um estudo de caso: o Hospital Santa Cruz da Sociedade Portuguesa de Beneficência de Niterói. In: SARGES, Maria de Nazaré et al (orgs.). Entre Mares: O Brasil dos Portugueses. Belém: Editora PakaTatu, 2010, p. 174-184.

MIRANDA, Cybelle Salvador; BELTRÃO, Jane Felipe; HENRIQUE, Marcio Couto. Caminhos e ausências no Patrimônio da saúde em Belém, Pará. Amazônica: Revista de Antropologia (Online), Belém - Pará, v.2, p. 308-343, 2013.

MONTEIRO, Miguel. Representações materiais do "Brasileiro" e construção simbólica do retorno. Camões Revista de Letras e Culturas Lusófonas, Lisboa, n. 11, pp. 100-119, out-dez 2000. (Pontes Lusófonas III Arquiteturas luso-brasileiras)

PEREIRA, Pedro Teixeira; GOMES, Eva; MARTINS, Olga. A alienação no Porto: o Hospital de Alienados do Conde de Ferreira (1883-1908). Revista da Faculdade de Letras HISTÓRIA, Porto,

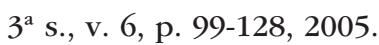

SÁ, Isabel dos Guimarães. Misericórdias, Portugueses no Brasil e Brasileiros. In: Comissão Nacional para as Comemorações dos Descobrimentos Portugueses - Os Brasileiros de TornaViagem no Noroeste de Portugal. Lisboa: CNCDP, 2000, p. 117-133. Disponível em: http://hdl. handle.net/1822/4341. Acesso em: 27 ago 2012.

SANTOS, José Coelho dos. O Palácio de Cristal e a Arquitectura do Ferro no Porto em meados do século XIX. Porto: Fundação Engenheiro Antonio de Almeida, 1989.

SARGES, Maria de Nazaré. Memórias do "velho" Intendente: Antonio Lemos - 1869-1973. 1998. Tese (Doutorado em História Social do Trabalho) - Instituto de Filosofia e Ciências Humanas, Universidade Estadual de Campinas, Campinas, 1998. 
SARGES, Maria de Nazaré. Belém: riquezas produzindo a belle-époque (1870-1912). Belém: Paka-Tatu, 2002.

SERRÃO, Vítor. A Cripto-História da Arte - análise de Obras de Arte Inexistentes. Lisboa: Livros Horizonte, 2001.

SOUSA, Alberto. Arquitetura neoclássica brasileira: um reexame. São Paulo: PINI, 1994.

SOUZA, Roseane Silveira de. Teatro da paz: histórias invisíveis em Belém do Grão-Pará. Anais do Museu Paulista, São Paulo, v. 18, n. 2, p. 93-121, jul-dez 2010.

\section{SÍTIOS}

Álbum da Colônia Portuguesa no Brasil, 1929.. Disponível em: www.ufpadoispontozero.com. br. Acesso em: 10 de ago. 2015

Arquivo Municipal do Porto. Disponível em: http://gisaweb.cm-porto.pt/. Acesso em: 15 jun 2016.

Centro de Memória da Universidade Federal do Pará. Disponível em: <http://www.ufpa.br/ cma/iconografias.html>. Acesso em: $1^{\circ}$ mar. 2010.

Hospital de Santo António. Disponível em: http://www.igespar.pt/pt/patrimonio/pesquisa/ geral/patrimonioimovel/detail/70197/. Acesso em: 24 abr 2014.

Artigo apresentado em 17/03/2016. Aprovado em 01/08/2016. 
